Published in final edited form as:

Annu Rev Pathol. 2009 ; 4: 199-227. doi:10.1146/annurev.pathol.4.110807.092222.

\title{
MicroRNAs in cancer
}

\author{
Yong Sun Lee ${ }^{1}$ and Anindya Dutta ${ }^{1,2}$ \\ ${ }^{1}$ Department of Biochemistry \& Molecular Genetics, University of Virginia, Charlottesville, VA 22908, \\ United States
}

\section{Abstract}

During the last few years, studies on microRNA (miRNA) and cancer have burst onto the scene. Profiling of the miRNome (global miRNA expression levels) has become prevalent and abundant miRNome data are currently available from various cancers. The pattern of miRNA expression can be correlated with cancer type, stage, and other clinical variables, so that miRNA profiling can be used as a tool for cancer diagnosis and prognosis. miRNA expression analyses also suggested oncogenic (or tumor suppressive) roles of miRNAs. miRNAs play roles in almost all aspects of cancer biology such as proliferation, apoptosis, invasion/metastasis, and angiogenesis. Given that many miRNAs are deregulated in cancers but have not yet been further studied, it is expected that more miRNAs will emerge as players in the etiology and progression of cancer. miRNAs will be also discussed as a tool for cancer therapy.

SYNOPSIS-During the last decade, a major discovery in biology was the discovery of small RNAs, including miRNA (microRNA) and siRNA (small interfering RNA), as highlighted by the 2002 December issue of Science magazine (1). Since RNA interference (RNAi) phenomenon was discovered in nematodes (2), siRNA has provided a technical breakthrough for short term genetics in mammalian systems. The big impact of small RNAs was well celebrated by the 2006 Nobel prize awarded to the two scientists who discovered RNAi.

On the other side, miRNAs shed new insight on the post-transcriptional regulation of gene expression. miRNAs were also first discovered in worms $(3,4)$, and later in a number of animals, plants, and viruses. During the last couple of years, the miRNA field has been expanding with many recent publications implicating miRNAs in diverse cellular processes.

Cancer is a major cause of death in the United States ("Cancer Facts \& Figures 2007" from American Cancer Society; http://www.cancer.org/docroot/stt/stt_0.asp). Cancer is a complex genetic disease caused by the accumulation of mutations that lead to deregulation of gene expression and uncontrolled cell proliferation. Given the wide impact of miRNAs on gene expression, it is not surprising that a number of miRNAs have been implicated in cancer. In this review, the links between miRNA and cancer will be comprehensively described and discussed.

\footnotetext{
${ }^{2}$ Corresponding author; 434-924-1227 (phone), 434-924-5069 (fax), ad8q@ virginia.edu CONCLUDING REMARKS

The discovery of miRNAs has provided a new layer in the regulation of gene expression. In addition to transcriptional regulation, posttranscriptional repression by miRNAs might act like "rheostats" for fine-tuning of gene expression. miRNAs at end stages of differentiation may contribute to keeping cells differentiated by suppressing a large number of genes simultaneously. In recent years, there has been an explosion of publications on miRNAs. Many of these have emphasized the role of miRNAs in cancer biology. miRNAs play a role in almost all aspects of cancer biology such as proliferation, apoptosis, invasion/metastasis, and angiogenesis. New techinical developments are allowing the description of a variety of cancers miRNomes. Therefore, more miRNAs are expected to be identified as oncogenes or tumor suppressors. Characterization of individual miRNA pathways will be greatly facilitated by an improvement of target prediction algorithm.

miRNA expression is associated with clinical variables of cancers, so that miRNAs can be readily used as tools for cancer diagnosis and prognosis. For therapeutic benefit, the methods to manipulate miRNAs in vivo should become more robust.
} 


\section{Keywords}

microRNA; cancer; tumorigenesis; oncogene; tumor suppressor; microRNA expression profile; diagnosis and prognosis; therapy

\section{INTRODUCTION}

MicroRNAs (miRNAs) are small non-coding regulatory RNAs with sizes of 17-25 nucleotides (miRBase; http://microrna.sanger.ac.uk/). The definition of miRNAs is based on their generation by the action of Dicer, an RNase that processes hairpin structured precursors (called pre-miRNA) into mature miRNAs (5). miRNAs post-transcriptionally repress gene expression by recognizing complementary target sites in the 3 'untranslated region (UTR) of target mRNAs.

Since the first miRNA was reported by Ambros and Ruvkun $(3,4)$ in 1993, it took eight years for the miRNA era to begin in earnest when three groups identified tens of small RNAs from C. elegans, Drosophila, and human (6-8). During the last seven years, the number of miRNAs as well as related publications have expanded enormously.

\section{Genes, sequences, and genomic organization}

Currently, more than 5,000 miRNAs from over 50 organisms are registered in the database (miRBase Release 10.0: August 2007). 533 human miRNAs are known now but this number may rise, as up to 1000 miRNAs are predicted to exist from bioinformatic studies $(9,10)$. miRNAs are named as miR- plus numbers, bearing a few exceptions. miRNAs of similar sequence are usually distinguished by an additional letter $(\mathrm{a}, \mathrm{b}, \mathrm{c} . .$.$) following the miRNA$ number (e.g. miR-125b). A miRNA of identical mature sequence may appear at several genomic loci with different precursor sequences. In this case, the different miRNA genes are distinguished by the addition of another number $(1,2,3 \ldots)$ at the end (e.g. miR-125b-1).

In humans, approximately one third of miRNAs are organized in clusters. A given cluster is likely to be a single transcriptional unit, suggesting a coordinated regulation of miRNAs in the cluster. In silico analysis revealed that more than half of the clusters contain two or more miRNAs of similar sequence (11). However, it is very rare that miRNAs of an identical mature sequence are duplicated in a cluster. This genomic organization confers simultaneous expression of similar miRNAs, possibly leading to combinatorial diversity and synergy in the biological effects. However, it is worth noting that all the miRNAs from a single transcriptional cluster are not expressed at equal levels, suggesting that miRNAs are also regulated posttranscriptionally.

A significant portion of miRNAs are located in the intronic region of protein-coding or noncoding transcription units (12), while a minor subset of miRNAs are mapped to repetitive sequences such as LINEs (long interspersed nuclear elements) (13).

\section{Expression}

Many miRNAs exhibit characteristic expression pattern. Some miRNAs are differentially expressed in developmental stages, like the two founding members, lin-4 and let-7 in $C$. elegans. For this reason, they were once called stRNA (small temporal RNA) because they are expressed in specific temporal phases of development and regulate the developmental timing. Many miRNAs are expressed in a tissue-specific manner. In the few cases where a forward genetic approach in worms or flies led to identification of a miRNA, the function of the miRNA can be inferred from the phenotype of the mutant. In mammalian cells, however, a miRNA 
expression profile is usually the first clue for its possible role. Analogous to mRNA expression, miRNA expression is determined by intrinsic cellular factors as well as diverse enviromental variables.

Expression of a miRNA can be measured by molecular biology techniques, such as Northern blot, RNase protection assay or primer extension assay. The small size of miRNAs initially hampered PCR-based methods. However, since adaptor mediated qRT-PCR (quantitative real time-PCR) protocols were developed (reviewed in (14)), PCR-based techiniques have now become very popular due to their high sensitivity. Microarray techniques (reviewed in (15)) are widely used to comprehensively assay the entire miRNome (global miRNA expression profile) in tissues or cell lines (Table 1). Besides microarray or qRT-PCR, miRNomes have been obtained by in situ hybridization (16) or SAGE (serial analysis of gene expression) adapted for small RNAs (17). The SAGE approach has been stimulated by recent innovations in ultra-high-throughput sequencing that provide a powerful tool for various genomics studies. Overall, these technical improvements are expected to greatly widen the repertoire of miRNAs in a variety of biological systems.

\section{Biogenesis}

Biogenesis of a miRNA begins with the synthesis of a long transcript called a pri-miRNA (Fig 1). In general, pri-miRNAs are transcribed by RNA polymerase II and retain mRNA features such as $5^{\prime}$ cap structure and $3^{\prime}$ poly(A) tail $(18,19)$. However, other pathways generate in a minor set of miRNAs especially from genomic repeats. For example, RNA polymerase III is responsible for transcription of miRNAs in Alu repeats (20).

In the nucleus, pri-miRNA is processed to pre-miRNA by RNase III enzyme Drosha and its interacting partner DGCR8 (21-23). DGCR8 recognizes the stem and the flanking single stranded RNA (ssRNA) and serves as a ruler for Drosha to cut the stem approximately 11 nucleotides away from the stem-ssRNA junction to release the hairpin-shaped pre-miRNA (24). A subset of miRNAs (miRtrons) bypass the Drosha requirement, by taking an alternative pathway where pre-miRNAs are derived as a by-product of a splicing event (25-27). The premiRNA is exported by exportin- 5 to the cytoplasm $(28,29)$ and converted to mature duplex miRNA by another RNase III enzyme, Dicer (30). The two strands of the duplex are separated by a RNA helicase (31) during the specific assembly of a miRNA particle (miRNP). Like the strand selection of an siRNA $(32,33)$, the strand whose 5 'end forms the more unstable duplex with its partner seems to preferentially survive as the miRNA in the miRNP $(24,32,33)$.

However, detailed molecular events during the miRNP assembly and strand selection are not yet clear.

\section{Mechanisms of action}

miRNAs post-transcriptionally suppress the target mRNA expression, mostly through interaction with the $3^{\prime}$ UTR (Fig 1). However, the exact mechanism for miRNAs on their targets is still controversial (reviewed in (34)). Unlike perfect sequence complementarity between siRNA and mRNA, there are mismatches and bulges in most miRNA target sites. Comparison between siRNA and miRNA in earlier papers suggested that siRNA destabilizes mRNA whereas miRNA inhibits mRNA translation without affecting the mRNA level. Therefore, the degree of complementarity between short RNA and target was thought to be a major determinant distinguishing the two mechanisms.

Although the translational repression mechanism still holds true for many miRNAs, it has been also demonstrated in a number of publications that a miRNA can decrease the level of a target mRNA despite imperfect sequence complementarity between the miRNA and the target (35-38). mRNA degradation by a miRNA, which is distinguished from siRNA-mediated 
mRNA cleavage, can be explained by RNA processing bodies (P-bodies), sites for RNA decay $(39,40)$. Plausibly, miRNAs inhibits translation of target mRNAs which are then sequestered to P-bodies and subject to degradation. This model fits well for both mechanisms, though miRNAs have also been proposed to lead to the degradation of the target mRNAs without sequestration to P-bodies $(41,42)$. In some cases where mRNA translation is inhibited by a miRNA but mRNA level stays similar, sequestration to P-bodies might be inefficient. Nonetheless, it is an open possibility that different mechanisms apply to individual miRNAmRNA interactions.

\section{Target prediction and identification}

Prediction of miRNA target is important, given that miRNAs exert their function by regulating the target mRNAs. The specificity of miRNA-mRNA interaction is mainly conferred by the first eight nucleotides of a miRNA (called seed sequence) (43). Besides seed pairing, the likelihood that a predicted target is a bona fide target is influenced by other factors such as the number of target sites, context of surrounding sequence in mRNA (44), and occlusion of target sites by RNA-binding proteins (45). Currently, several computational algorithms (reviewed in (46)) are available to predict the target mRNA(s) but they are far from perfect. The gold standard is experimental demonstration that a luciferase reporter fused to the $3^{\prime} \mathrm{UTR}$ of the predicted target is repressed by overexpression of the miRNA and that this repression is abrogated by point mutation in the target sequence $(\mathrm{s})$ in the $3^{\prime} \mathrm{UTR}$. Many targets are predicted by in silico analyses but all of them are not confirmed as real targets in this biological assay.

The in silico predictions have been complemented by experimental screenings for targets of miRNAs. As miRNAs destabilize mRNAs, miRNA depletion by a knockdown of miRNA processing machinery is expected to result in upregulation of target mRNA, which can be assayed by microarray analysis. This approach identified HMGA2 as a target of let-7 (38). Microarrays can also identify mRNAs that are decreased upon transfection of a miRNA and screening these mRNAs for computationally predicted sites targeted by the miRNA yields some bona fide targets (37). A proteomics approach to identify proteins decreased by miRNAs led to the identification of tropomyosin 1 (TPM1) as a miR-21 target (47). Another screen employed a library of miRNA-expressing vectors and a sensor plasmid containing GFP fused with the 3'UTR of the gene of interest. p27(Kip1) was found to be targeted by miR-221 and -222 by this approach (48). Another approach is to isolate miRNA-target mRNA complex by immunoprecipitation of a RISC component followed by microarray hybridization of the precipitated mRNAs (49).

Although a growing number of miRNA-target pairs are being identified (Table 4), the fraction of validated pairs are still small, given that $30 \%$ of mRNA have been predicted to be miRNA targets $(50,51)$. New target identification will be faciliated by the accumulation of validated miRNA-target pairs which can be utilized to develop a better prediction algorithm. In addition, experimental tools for high-throughput target screening need to be improved.

\section{Biological roles}

miRNAs play important roles in cell fate determination, proliferation, and cell death. Besides these vital processes, miRNAs are implicated in diverse cellular activities, such as immune response (reviewed in $(52,53)$ ), insulin secretion $(54)$, neurotransmitter synthesis $(55)$, circadian rhythm (56), viral replication (57), etc. This list will undoubtedly expand as experimental data accumulate.

miRNA transfection results in up- and down-regulation of a number of mRNAs. In several cases, a set of genes belonging to a particular cellular pathway are enriched in the list of genes whose expression was altered. $(35,58-62)$. The length of miRNA seed sequence is comparable 
to that of the consensus sequence of transcription factor binding elements. Thus, although miRNAs are expected to directly regulate a large set of genes simultaneously, random chance is unlikely to explain the enrichment of genes in a particular pathway in the list of putative targets.

\section{MIRNA AND CANCER}

\section{Profiling of miRNA expression in cancers}

miRNAs are aberrantly expressed in a variety of cancers. The first example was miR-15a and -16-1 which are clustered at chromosome 13q14, a frequently deleted region in B cell chronic lymphocytic leukemia (CLL) and other cancers (63). Concomitantly, reduction of these two miRNAs was observed in the cancer samples relative to the normal tissues.

miRNome analyses have become easier by microarray techniques (Table 1). Many miRNAs are found to be up- or down-regulated in the cancer samples relative to the normal tissue counterparts (Table 2). It is beyond the capacity of this review to describe all the miRNAs that are changed in cancers from profiling data. Instead, in Table 1 we have summarized the literature reporting miRNomes in tumors. If a change in miRNA expression has been corroborated by a conventional method (Northern, RNase protection assay, or qRT-PCR), it was included in Table 2.

In addition to the distinction of tumors from normal tissue, miRNA expression is characteristic for a cancer type, stage, and other clinical variables. The first systematic analyses of hundreds of cancer samples and normal tissues (64) successfully classified various cancers based on the miRNome. It was surprising that the miRNome was better at predicting cancer type and stage than the mRNA expression profile and therefore was proposed as an useful tool for cancer diagnosis or prognosis. For example, clustering of CLL samples according to the miRNome revealed miRNA signatures that correlated with overexpression of ZAP-70, a predictor of early disease progression (65). The utility of miRNA in diagnosis will be discussed later.

Although some miRNAs are increased, most miRNAs are repressed in cancers relative to normal tissue counterparts $(64,66-69)$. In agreement with these observations, global depletion of miRNAs by knockdown of the miRNA processing machinery stimulated cell transformation and tumorigenesis in vivo (70). This implies that the miRNA alteration is not simply an end result of tumorigenesis but actively contributes to cancer development. Despite the general reduction of miRNAs in cancers, there are several miRNAs that are up-regulated, some of which undoubtedly play oncogenic roles.

\section{Mechanism for miRNA deregulation in cancers}

As documented in the previous section, many miRNAs are deregulated in cancers. Aberrant expression of miRNAs can arise through a number of different mechanisms (Fig. 2).

1. Genomic abnormality-As exemplified by miR-15a and -16-1, chromosomal abnormality is one reason for miRNA deregulation in cancers. Tumorigenesis is often accompanied by chromosomal aberration such as deletion, amplification, translocation, etc. In silico analysis revealed that a significant fraction of miRNAs are mapped to these cancerassociated genomic regions or fragile sites in human (71) and mouse (72). In many cases, miRNA levels are correlated with changes in copy number of the genomic loci, as demonstrated by comparison between array CGH (comparative genomic hybridization) data and miRNA expression data (66,73-78).

2. Epigenetic factors-Epigenetic factors could also affect miRNA expression. In many cancers, hypermethylation of $\mathrm{CpG}$ islands in promoter regions results in heritable 
transcriptional silencing of tumor suppressor genes. Gene silencing by DNA methylation is closely related with histone modification. In silico analyses indicated $\mathrm{CpG}$ islands near dozens of miRNAs (79). In addition, some miRNAs were up-regulated upon exposure of cells to the demethylating agent 5-aza-2'-deoxycytidine (79), upon mutation of DNMTs (DNA methyltransferases) (80), or upon HDAC (histone deacetylase) inhibitor treatment (81). These studies identified some miRNAs which are repressed by $\mathrm{CpG}$ hypermethylation in cancers relative to normal tissue. Representative examples are miR-9-1 in breast cancer (79) and miR-124a in colorectal tumors (80). In case of miR-124a, hypermethylation is tumor-type specific, as no methylation was seen in neuroblastoma. Epigenetic silencing of a miRNA may be a reflection of tissue specificity. For example, miR-124a is normally highly expressed in neuronal tissues, so that its epigenetic repression in colorectal tumors is not surprising.

miRNAs may counteract CpG methylation. For example, miR-29 directly targets DNA methyltransferases Dnmt3A and -3B. In agreement with this, ectopic expression of miR-29 resulted in a global reduction of DNA methylation, subsequently leading to a de-repression of some tumor suppressor genes which had been silenced by promoter methylation in cancer cells (82).

3. Transcriptional regulation-Transcription factors may induce miRNAs by activating the transcription of pri-miRNAs. This mechanism is well documented in several cases where tissue specific miRNAs are turned on by transcription factors during differentiation. Given the wide impact of transcription factors in fundamental cellular processes, it is obvious that many oncogenes or tumor suppressors are transcription factors. Many miRNA-transcription factor relationships have been discovered in cancers, as listed in Table 3. Among them, p53, c-Myc, and E2F will be elaborated later.

4. Regulation at miRNA processing steps-In addition to the transcription rate of primiRNA, the steady state level of a mature miRNA is determined by the processing efficiency of its precursors and by its stability. miRNAs often exhibit a discrepancy in expression of the mature form relative to that of a precursor (83-88). Although miRNAs in a genomic cluster are usually expressed from a common pri-miRNA, the levels of individual miRNAs in the cluster are not necessarily coordinated (89,90). A time course experiment after induction of pri-miR-21 revealed a delayed kinetics in accumulation of mature miR-21 (91). Collectively, these observations indicate that miRNA processing and stability are important factors that determine miRNA expression level.

This mechanism has been underscored in cancers by a comprehensive analyses of expression data (92). miRNAs are generally reduced in cancers relative to the normal tissues. In cases where a miRNA resides within a gene, host genes can be regarded as the pri-miRNA. Comparison of microarray data between mRNA and miRNA revealed that the miRNA reduction in cancers is poorly correlated with a reduction of the host gene expression. Aberrant expression of miRNAs during tumorigenesis is presumably often due to alterations at posttranscriptional steps.

The expression levels of Dicer or Drosha were altered in a number of cancers (70,93-96). Drosha up-regulation is seen in more than half of cervical SCC (squamous cell carcinoma) specimens and is likely due to the copy number gain at chr5p where the Drosha gene is located (95). Hierarchial clustering of miRNA expression data successfully classified cervical SCC samples into two groups according to Drosha overexpression. It is noteworthy that some miRNAs were reduced upon Drosha overexpression, indicating that individual miRNAs respond differentially to an elevation of the miRNA processing machinery. Interestingly, Drosha was reported to interact with an oncogenic fusion protein derived from a chromosomal 
translocation in some leukemias (97). This interaction affected pri-miRNA selection of Drosha and, as a result, miRNA expression pattern.

\section{Consequence of aberrant miRNA expression in cancers}

miRNAs regulate the expression of their target mRNA, so that over- or under-expression of miRNAs is expected to respectively result in down- or up-regulation of the protein product of target mRNAs. It is easy to implicate a miRNA in a cancer if a direct target of a miRNA is an oncogene or a tumor suppressor. Since let-7 miRNA was shown to directly regulate $R A S$ oncogene (98), a number of other miRNA-target pairs have been studied. However, the number of experimentally validated pairs is still small relative to the number of miRNAs shown to be aberrantly expressed in tumors or the number of in silico predicted pairs, mostly because current target prediction algorithms are not very accurate. A current list of miRNA-target pairs implicated in various cancers is in Table 4, and important examples will be discussed later.

If global gene expression profiles are compared between cancers and normal tissues, many miRNAs and mRNAs are found to be deregulated. Therefore, it is very plausible that tumorigenesis or at least the progression of a cancer results from changes in the entire miRNome, rather than from the change of a single miRNA which regulates an oncogenic (or tumor suppressive) target gene.

Some miRNAs appear to be deregulated in cancers much more frequently than other miRNAs (Table 2). These miRNAs may play key roles during tumorigenesis. For example, the miR-17-92 cluster and miR-155 have been experimentally demonstrated to be bona fide oncogenes, as their ectopic expression accelerated tumor development. These two miRNAs will be described in detail in separate sections.

\section{Aberrant action of miRNAs without alteration of miRNA expression level}

The function of protein-coding genes are rendered abnormal by point mutations which transform proto-oncogenes to oncogenes or abrogate functions of tumor suppressor genes. In theory, the same mechanism of activation/inactivation may apply to miRNAs. However, variation in mature miRNA sequence seems to be a very rare event $(72,99-101)$, presumably due to the small size. In addition, miRNAs are thought to be more tolerant of point mutations or of single nucleotide insertion/deletion mutation than protein coding genes.

In contrast, sequence variation in miRNA target sites may occur and play a role in cancer. In silico analysis of EST (expressed sequence tag) and SNP (single nucleotide polymorphism) databases indicated different allele frequencies of miRNA binding sites in cancers versus normal tissues (102). In a few experimental results, sequence polymorphisms in miRNA target sites were shown to affect miRNA-mRNA interaction and implicated in disease phenotypes (100,103-105) (Fig 2).

With regard to this mechanism, an interesting example is let-7 and its direct target oncogene HMGA2 $(38,106)$. Chromosomal rearrangements at the HMGA2 locus in several tumors separate the ORF from the $3^{\prime} \mathrm{UTR}$ containing let-7 target sites. As a result, HMGA2 escapes from suppression by let-7, is overexpressed, and promotes tumorigenesis (Fig 2).

An alternative splicing event may result in a different $3^{\prime}$ UTR that displays different miRNA target sites, as exempified in the targeting of tropomyosin-related kinase $\mathrm{C}(\operatorname{trkC})$ by miR-9, $-125 \mathrm{a}$, and $-125 \mathrm{~b}$. One mRNA isoform encodes a truncated ORF that is functionally dominant negative to the intact protein. In this isoform, the $3^{\prime}$ UTR contains the target sites of these miRNAs. In contrast, the target sites are absent in another isoform encoding the intact ORF. Only the former isoform was repressed by the miRNAs (107). Although the stop codon is usually located in the last exon, generation of different $3^{\prime}$ UTRs by alternative splicing has been 
known to occur in a small but significant fraction of genes (108). Thus, variation of $3^{\prime} \mathrm{UTR}$ and of attendant miRNA target sites is expected to be a mechanism for oncogene activation or tumor suppressor inactivation (Fig 2).

Recently, Steitz and colleagues reported that miRNAs activate the translation of the target mRNA in cells arrested at G0/G1 stage (109). Besides aberrant miRNA expression, the switch from repression to activation should be considered in studying miRNA role in differentiation or tumorigenesis, as the same miRNA may exert an opposite effect between resting cells in a tissue and proliferating cancer cells.

\section{Viruses and miRNAs in tumorigenesis}

Several viruses regulate tumorigenesis by expressing viral oncogenes or activating cellular oncogenes through integration of viral DNA into genomic loci. Both mechanisms are applicable to oncogenic miRNAs. For example, the Epstein Barr virus (EBV)-encoded miRNAs (110) directly target a viral oncogene LMP1 whose overexpression is deleterious to host cells. EBV miRNAs are thought to enhance EBV mediated cellular transformation by adjusting LMP1 level to a sub-lethal dose (111). In another case a viral miRNA repressed a host tumor suppressor gene miRNAs from Kaposi sarcoma-associated herpesvirus (KSHV) directly targets an anti-angiogenic factor thrombospondin-1 (112). Thus viral miRNAs act as viral oncogenes.

Viral integration near miRNA loci may lead to aberrant expression of miRNAs. Indeed, miR-155 (BIC is the pri-miRNA) was originally described as a frequent integration site in virally induced lymphomas (113). Viral integration sites are often mapped to miRNA loci (114), such as the miR-17-92 cluster (115), miR-106a-363 cluster (116), miR-29a-29b-1 cluster (117), and miR-106a cluster (118).

\section{Various cancer types}

Comprehensive miRNA profiles have been reported with clinical specimens from various cancers. The data are summarized in Table 1. Consistent with the notion that miRNAs are expressed in a tissue specific manner, miRNAs are different among cancers from various tissue origins. There are also a couple of miRNAs that appear to be frequently deregulated in many cancers (Table 2), suggesting that these miRNAs regulate fundamental processes such as cell proliferation or apoptosis.

\section{Oncogenic or tumor suppressive miRNAs}

1. miR-17-92 cluster-The miR-17-92 cluster, located at chr13q31.3 in humans, is composed of six miRNAs (mir-17,-18a, -19a, -20a, -19b-1, and -92a-1). There exists a similar cluster at chrX called miR-106a-363 cluster (mir-106a, -18b, -20b, -19b-2, -92a-2, and -363). The miR-17-92 cluster contains the first miRNAs demonstrated to be oncogenic. The development of B-cell lymphoma was significantly accelerated by the forced expression of the miR-17-92 cluster in transgenic mice overexpressing c-myc oncogene (119).

Consistent with its oncogenic role, the miR-17-92 cluster is up-regulated in a variety of cancers including lymphomas $(74,75,119,120)$, lung cancers $(77,121)$, and others $(122)$. There appear to be two mechanisms for up-regulation of this cluster in cancers (Fig 3). One is the amplification of chr13q31 locus in several lymphomas and other cancers $(74,77,78,120)$. The other is transcriptional activation of the pri-miRNA. An oncogenic transcription factor c-Myc binds the genomic locus upstream of the miR-17-92 cluster and activates its expression (123). In neuroblastoma cells, MycN, a protein highly homologous to c-Myc, appears to activate this cluster instead of c-Myc (124). E2Fs also activate this cluster $(125,126)$ (Table $3)$. 
Given that E2Fs are direct targets of miR-17 and -20a, the miR-17-92 cluster constitute a very complex regulatory network with c-Myc and E2Fs. E2F1 and c-Myc are known to activate each other to form a positive feedback loop (Fig 3). All of E2Fs (E2F1, 2, and 3) are capable of activating miR-17-92 cluster and are subject to repression by miR-17 and -20a from this cluster (Table 4). However, degrees of activation and repression are variable between individual pairs of miRNA and E2F family member. In general, E2Fs are thought to be proproliferative, but E2F1 is also pro-apoptotic. Although this network is too complicated to describe in a straightforward manner, the miR-17-92 cluster is clearly responsible for finetuning the regulatory network. Upon a proliferative cue, c-Myc and E2Fs turn on the miR-17-92 cluster. This cluster represses E2Fs, thereby preventing the uncontrolled amplification of the positive feedback loop between E2Fs and c-Myc. In addition, repression of E2F1 by the miRNAs may help minimize the pro-apoptotic potential of E2F1. This network is depicted in Fig 3.

2. $\mathbf{m i R}-21-m i R-21$ is up-regulated in almost all kinds of cancers (Table 2). It has been shown that miR-21 is transcriptionally activated by Stat 3 (signal transducer and activator of transcription 3) in the IL-6 signaling pathway (91) (Table 3). miR-21's role is well characterized in invasion and metastasis, which will be further discussed later.

3. miR-155-Like the miR-17-92 cluster, the oncogenic potential of miR-155 was demonstrated by transgenic mice expressing miR-155 in B-cells (127). The primary transcript for miR-155 is the BIC gene, which was originally known as a common viral integration site in lymphomas in chicken. High expression of miR-155 (BIC) is reported in various B-cell malignancies (128-130) (Table 2). miR-155 seems to be regulated at multiple levels. Besides viral integration, miR-155 (BIC) appears to be regulated by NF- $\mathrm{kB}$ through the B cell-receptor (BcR)-mediated signaling pathway (85) or through the Toll-like receptor (TLR) activated signaling pathway (131). However, a discrepancy between the level of miR-155 and BIC suggests that miR-155 may also be regulated during processing steps (129). For example, the induction of BIC does not lead to up-regulation of miR-155 in several Burkitt lymphoma cell lines. In contrast, miR-155 is concordantly increased upon the induction of BIC in Raji, an EBV latency type III positive Burkitt lymphoma cell line (85).

4. let-7-let-7 is one of the earliest discovered miRNAs. In human, there are 12 paralogous let-7s. Whereas let-7 is almost absent during embryonic stages or tissues, high expression of let-7 is seen in most differentiated tissues. The reduction of let-7 in cancers is reminiscent of let-7 expression during development in that it is most decreased in less differentiated, advanced stages of cancer cells with mesenchymal characters (132).

Probably, let-7 is more abundant than any other miRNAs, so that reduction of let-7 may exhibit a prominent effect on cell physiology compared to other miRNAs. To support this hypothesis, enhanced cellular transformation by global miRNA depletion was largely recapitulated by inhibition of let-7 alone (70). Well known oncogenes such as RAS, c-Myc, and HMGA2 are validated as direct targets of let-7 (Table 4). Hence, let-7 is an important tumor suppressor.

5. miR-34s (miR-34a and miR-34b/-34c cluster)-miR-34s acquired recent notoriety because they are induced by p53 (Fig 4). Consistent with p53 being a tumor suppressor, miR-34s were down-regulated in several tumors such as non-small cell lung cancers (NSCLCs) (60) and pancreatic cancers (61) (Table 2). However, the reduction of miR-34s is not always correlated with p53 loss, suggesting a p53 independent mechanism of miR-34 reduction in some cancers. In fact, miR-34a is located in $1 \mathrm{p} 36$, a locus frequently deleted in a number of cancers (76). p53 regulation and miR-34s roles will be elaborated later. 
Although miR-34s are thought to be tumor suppressors, they were found to be up-regulated in several cancers including renal cell carcinoma (133), colon cancers (58), and hepatocellular carcinoma (134) (Table 2). The role of high miR-34 and p53 status awaits investigation in these tumors.

\section{Aspects of cancer biology regulated by miRNAs}

1. Cell cycle-Cell cycle regulators often act as oncogenes or tumor suppressors. The best characterized example is a cell cycle inhibitor p27(Kip1).p27(Kip1) is a tumor suppressor, as indicated by low levels in some cancers. In addition, p27(Kip1) mutation predisposes cells to tumorigenesis upon exposure to carcinogens. p27(Kip1) binds to Cdk2-cyclin E and prevents G1 to $\mathrm{S}$ transition. p27(Kip1) is a direct target of miR-221 and -222 in glioblastomas (48, 135 ) and prostate cancer cells (136). In these cancer cells, p27(Kip1) is anti-correlated with these two miRNAs. Targeting p27(Kip1) is responsible for the pro-proliferative role of these miRNAs, as artificial knockdown of p27(Kip1) mirrored the phenotype of these miRNAs. miR-221 and -222 are overexpressed in other cancers (see Table 2), implying their role in a wide range of cancers.

Besides p27(Kip1), miRNAs regulate other cell cycle proteins including Cdk6, Cdc25A, Ccnd2 (cyclinD2) (59), Cdk4 (62), a Rb family protein (89), and p180 of DNA polymerase $\alpha$ (37). A number of miRNAs have been shown to perturb normal cell cycle when overexpressed or inhibited. (37,48,62,70,137-139) (Table 5). Oscillation of a miRNA during the normal cell cycle has not yet been reported.

2. Programmed cell death-Apoptosis is an active process controlled by a gene expression program that varies depending on the biological context. Since a balance between proliferation and apoptosis is essential for tissue homeostasis and proper differentiation, aberrant apoptosis may give rise to tumors. miRNAs participate in tumorigenesis by directly targeting antiapoptotic genes. Representative examples are the repression of anti-apoptotic genes Mcl-1 and Bcl-2 by miR-29b (84) and miR-34s (60), $-15 a$, and -16 (140), respectively (Table 4$)$. The loss of these miRNAs due to mutation of p53 or deletion of chr13q14 leads to an increase in the anti-apoptotic gene expression and persistence of tumor cells that would have been normally removed by apoptosis. It is very likely that miRNAs may target other genes in the apoptotic pathway, since transfection or expression of a number of miRNAs is associated with apoptosis $(69,76,121)$ (Table 5).

3. p53-p53, a sequence-specific transcription factor, is called the guardian of the genome owing to its critical role in regulation of the cell cycle and apoptosis in the face of genomic damage. Genotoxic stress and oncogene activation activate p53 to modulate the transcription of several target genes. p53 is the most extensively studied tumor suppressor and its importance is underscored by mutation of p53 in almost $50 \%$ of human cancers.

miRNA profiling after $\mathrm{p} 53$ induction indicated miR-34a, $\mathrm{b}$, and c (miR-34s, collectively) as the most up-regulated miRNAs $(61,62,137,141)$ (Fig 4). These miRNAs are induced after genotoxic stress in a p53-dependent manner in vitro and in vivo $(62,141)$. miR-34b and -34c are clustered at chr11, while miR-34a is located in a separate genomic locus. Both pri-miRNAs are directly activated by $\mathrm{p} 53$. miR-34s seem to be a critical downstream effector of $\mathrm{p} 53$, since ectopic expression of miR-34s recapitulated the phenotype of $\mathrm{p} 53$ activation. miR-34s promote cell cycle arrest, apoptosis and senescence. $(58,60-62,137,141)$ (Table 5). These effects are explained by the repression of several direct targets of miR-34s, such as Bcl2 (60), Cdk4, and hepatocyte growth factor receptor (MET) (62) (Table 4).

Besides miR-34s, other miRNAs might be important in the p53 pathway. miR-30c, -103, -26a, -107 , and -182 were induced clearly, albeit less robustly, upon DNA damage in a p53 dependent 
manner (61). miR-26a expression was also shown to be dependent on p53 (142). In another approach, searching for p53 binding elements in DNA sequence near miRNAs identified miR-129 as a good candidate for regulation by p53 (143).

4. Invasion and metastasis-Features of maligant tumors, distinct from benign tumors, are invasion and metastasis. Malignant tumors are fatal, mostly due to their capacity to invade neighboring tissues and metastasize through the bloodstream to distant organs. An effect of miRNAs on invasion and migration has been reported (Table 5). Ectopic expression of miR-125 impaired cell motility and invasion in a breast cancer cell line (144). Reduction of global miRNA expression enhanced migration of cells (70).

These sporadic in vitro observations were followed by more detailed studies on miR-10b and miR-21. miR-21 is one of the most frequently up-regulated miRNAs in cancers (Table 2). miR-21 promotes cell motility and invasion by directly targeting PTEN, a tumor suppressor known to inhibit cell invasion by blocking the expression of several MMPs (matrix metalloprotease) (134). Recently, another pathway was reported in colorectal cancers where miR-21 promotes invasion, intravasation, and metastasis by down-regulating Pdcd4 (145)

miR-10b is the other miRNA implicated in metastasis. In metastatic breast cancer cells, miR-10b is up-regulated presumably as a result of transcriptional activation by Twist. Ectopic expression of miR-10b promoted invasion, intravasation, and metastasis in otherwise noninvasive or non-metastatic breast cancer cell lines. miR-10b directly targets Homeobox D10 whose reduction induces the expression of a well characterized pro-metastatic gene, RhoC (146).

5. Angiogenesis-Recruiting blood vasculature is crucial to the survival of neoplastic cells. So far, the miR-17-92 cluster has been characterized in this process. The stimulation of neovascularization by c-Myc involves a down-regulation of anti-angiogenic factor Tsp-1 (thrombospondin-1). c-Myc represses Tsp-1 and a related protein CTGF (connective tissue growth factor) by activating miR-17-92 cluster. Tsp-1 and CTGF seem to be direct targets of miR-19 and -18 in this cluster, respectively. Ectopic expression of the miR-17-92 cluster is sufficient for promoting angiogenesis (147). A recent observation suggested that other miRNAs, miR-378 and -27a, may play a role in angiogenesis $(139,148)$ (Table 5). Viral miRNAs may also play a role in angiogenesis, since Tsp- 1 was shown to be a direct target of KSHV miRNAs (112).

6. Others-The microenvironment inside a solid tumor is usually hypoxic. Tumor cells under hypoxia tend to be resistant to therapies and to be of poor prognosis. Up-regulation of some miRNAs under hypoxia $(149,150)$ (Table 3 ) suggests that these miRNAs could influence the phenotype of hypoxic tumor cells. Cancers are predisposed by other external factors, such as genotoxic stress, folate deficient diet, and exposure to arsenic. There are a few reports of miRNA profiles under these conditions $(151,152)$, but whether miRNA changes are responsible for the cancer predisposition remains to be investigated.

\section{Clinical applications}

1. Diagnositc tools-miRNAs may be used as diagnostic or prognostic tools, since miRNA expression profiles reflect tumor origin, stage, and other pathological variables. Practically, miRNAs can be accurate molecular markers because miRNAs are relatively stable and resistant to RNase degradation probably owing to the small size $(35,153,154)$. It has been shown that miRNAs can be isolated and quantitated from formalin-fixed paraffin-embedded (FFPE) specimens. qRT-PCR and microarray data were reliably and reproducibly obtained from FFPE 
samples which had been routinely processed and stored for 10 years. The data from FFPE samples were consistent with that from frozen samples $(155,156)$.

The development of qRT-PCR methods improved the sensitivity of miRNA detection down to a few nanograms of total RNA $(68,157,158)$. This amount can easily be obtained by fine needle aspiration biopsies (FNABs) and in fact, there is a report of successful miRNA measurement by qRT-PCR on FNAB samples (159).

miRNA markers that could be used for cancer diagnosis are becoming available. For example, miR-196a is high in pancreatic ductal adenocarcinoma (PDAC) but low in normal tissues and chronic pancreatitis. miR-217 exhibits the opposite expression pattern (Table 2). Thus, the ratio of miR-196a/-217 calculated by qRT-PCR measurement of the two miRNAs from tiny amount of total RNA, indicates whether the sample contains PDAC (160). Once reliable indicator miRNAs are chosen, we expect them to yield easy and accurate tools for cancer diagnosis.

2. Cancer therapeutic tool-A number of miRNAs affect the growth of cancer cells in vitro and in vivo when overexpressed or inhibited. Therefore, cancer cell growth can be controlled by manipulating miRNAs. Overexpression or inhibition of miRNAs can be achieved in several ways. Synthetic miRNA mimics include siRNA-like oligoribonucleotide duplex (161) or chemically modified oligoribonucleotide (162). Conversely, miRNAs can be inhibited by variously modified antisense oligonucleotides such as 2'-O-methyl antisense oligonucleotide, antagomirs and so on (reviewed in (163)). As the first successful tool for knockdown of a miRNA in vivo, antagomirs are of special interest (164). Antagomirs seem to be delivered to all tissues after tail-vein injections into mice, except brain. The therapeutic value of an antagomir would be greatly elevated by technical improvements for selective tumor-specific or tissue-specific delivery.

Synthetic oligonucleotides are effective in vivo for at most a couple of weeks, as demonstrated by an experiment with cancer cells engrafted in mice (165) or with tail-vein injection to mice (166). To circumvent this limitation, miRNAs can be stably expressed through transcription of hairpin RNA from plasmid vector (reviewed in (167)). Recently, artificial overexpression of a miRNA target sequence was shown to inhibit the miRNA function, presumably by titrating the miRNA away from endogenous targets $(168,169)$. Thus it should be possible to apply such competitive inhibitors for the long term sequestration of a miRNA.

Non-specific side effects are as important as effectiveness and duration of miRNA expression (or inhibition). In some examples, it has been argued that miRNA mimics or inhibitors are specific enough to distinguish between similar miRNAs $(170,171)$. However, crossreactivity between miRNAs of similar sequence is likely to be unavoidable at high doses of the antagonists or agonists. Another possible side effect is that high expression of miRNA mimics may interfere with endogenous miRNA action by saturating the cellular machinery for miRNA processing or action. This may result in a change in expression of other miRNAs leading to a deleterious effect in the cells. Indeed, a fatal side effect was reported to occur as a result of saturation of miRNA pathway (172). To minimize undesirable side effects, the expression or knock-down of a miRNA should be improved so that it is more accurate and controllable. An alternate approach to improve specificity is to target the pre-miRNAs with antisense or siRNA strategies $(173,174)$.

Some chemical compounds alter expression of a group of miRNAs (81). Thus it may be possible to screen for drugs that could shift the miRNome in a cancer cell towards that of the normal tissue. NCI-60 cancer cell lines may serve as a platform for this screening, as their miRNA expression profiles have been published $(68,175)$. By modulating multiple miRNAs 
simultaneously, such a miRNome modifying approach may be much more effective for therapy than strategies that aim to regulate a single miRNA.

miRNAs affect the drug sensitivity of a cell $(165,176)$ (Table 5). Expression or inhibition of a miRNA can therefore be combined with treatment of a drug or other cytotoxic therapy. One example is miR-21 inhibition together with a secreted form of tumor necrosis factor-related apoptosis inducing ligand (S-TRAIL), which resulted in a complete eradication of glioblastoma cells (177).

Collectively, preliminary results suggest that miRNAs could be useful for cancer therapy. However, there is still a significant gap between basic research on miRNAs and clinical application. Extensive preclinical and translational research is necessary to increase the efficacy and decrease the side effects of miRNAs in vivo. In parallel, we need to acquire more knowledge on the interaction of miRNAs with the gene expression programs and how these interactions are altered in tumorigenesis.

\section{Supplementary Material}

Refer to Web version on PubMed Central for supplementary material.

\section{Acknowledgments}

Work on microRNAs in the authors' lab was supported by grants from the Dept. of Defence (PC050114) and the NIH (AR053948).

\section{APPENDIX \\ Other small RNAs?}

Besides siRNAs and miRNAs, other types of small RNA have been reported in yeast, Drosophila, C. elegans, and plants. These small RNAs include tiny noncoding RNAs (tncRNAs), repeat associated small interfering RNAs (rasiRNAs), scan RNAs (scnRNAs), and others (reviewed in (178)). These RNAs are thought to be related to miRNA and siRNA, but are distinct from them. Recently, Piwi-interacting RNA (piRNA), another small RNA that is a little bigger than miRNA, were discovered from mammalian testes. Other classes of small RNA possibly exist but are yet to be discovered, given that a significant portion of transcripts are non-coding RNA. Whereas protein coding genes comprise only 1-2 \% of the human genome, significant fraction $(\sim 15 \%)$ of the human genome is transcribed and these transcripts still remain as a dark matter $(179,180)$. The discovery of noncoding RNAs is expected to be greatly stimulated by development of high-throughput deep sequencing techniques.

\section{Other diseases}

Besides cancers, miRNAs (or miRNA machinery) have been implicated in other diseases, for example, Tourette's syndrome (103), Fragile X syndrome (181), Digeorge syndrome (23), myotonic dystrophy, spinocerebellar ataxia type 3 (SCA3) (182), and schizophrenia and schizoaffective disorder (183). Of particular interest is myotonic dystrophy type 1 (DM1) which is characterized by expansion of CTG repeat in the $3^{\prime} \mathrm{UTR}$ of dmpk gene. Tandem CAG sequences are found in some miRNA seed sequences and thus are able to interact with the CTG repeats, raising the possibility that these miRNAs may be involved in DM1 pathogenesis (184). 


\section{REFERENCES}

1. Kennedy D. Science 2002;298:2283. [PubMed: 12493874]

2. Fire A, Xu S, Montgomery MK, Kostas SA, Driver SE, Mello CC. Nature 1998;391:806-11. [PubMed: 9486653]

3. Lee RC, Feinbaum RL, Ambros V. Cell 1993;75:843-54. [PubMed: 8252621]

4. Wightman B, Ha I, Ruvkun G. Cell 1993;75:855-62. [PubMed: 8252622]

5. Ambros V, Bartel B, Bartel DP, Burge CB, Carrington JC, et al. Rna 2003;9:277-9. [PubMed: 12592000]

6. Lagos-Quintana M, Rauhut R, Lendeckel W, Tuschl T. Science 2001;294:853-8. [PubMed: 11679670]

7. Lee RC, Ambros V. Science 2001;294:862-4. [PubMed: 11679672]

8. Lau NC, Lim LP, Weinstein EG, Bartel DP. Science 2001;294:858-62. [PubMed: 11679671]

9. Bentwich I, Avniel A, Karov Y, Aharonov R, Gilad S, et al. Nat Genet 2005;37:766-70. [PubMed: 15965474]

10. Berezikov E, Guryev V, van de Belt J, Wienholds E, Plasterk RH, Cuppen E. Cell 2005;120:21-4. [PubMed: 15652478]

11. Yu J, Wang F, Yang GH, Wang FL, Ma YN, et al. Biochem Biophys Res Commun 2006;349:59-68. [PubMed: 16934749]

12. Rodriguez A, Griffiths-Jones S, Ashurst JL, Bradley A. Genome Res 2004;14:1902-10. [PubMed: 15364901]

13. Smalheiser NR, Torvik VI. Trends Genet 2005;21:322-6. [PubMed: 15922829]

14. Schmittgen TD, Lee EJ, Jiang J, Sarkar A, Yang L, et al. Methods 2008;44:31-8. [PubMed: 18158130]

15. Liu CG, Spizzo R, Calin GA, Croce CM. Methods 2008;44:22-30. [PubMed: 18158129]

16. Wienholds E, Kloosterman WP, Miska E, Alvarez-Saavedra E, Berezikov E, et al. Science 2005;309:310-1. [PubMed: 15919954]

17. Cummins JM, He Y, Leary RJ, Pagliarini R, Diaz LA Jr. et al. Proc Natl Acad Sci U S A 2006;103:3687-92. [PubMed: 16505370]

18. Cai X, Hagedorn CH, Cullen BR. Rna 2004;10:1957-66. [PubMed: 15525708]

19. Lee Y, Kim M, Han J, Yeom KH, Lee S, et al. Embo J 2004;23:4051-60. [PubMed: 15372072]

20. Borchert GM, Lanier W, Davidson BL. Nat Struct Mol Biol 2006;13:1097-101. [PubMed: 17099701]

21. Lee Y, Ahn C, Han J, Choi H, Kim J, et al. Nature 2003;425:415-9. [PubMed: 14508493]

22. Denli AM, Tops BB, Plasterk RH, Ketting RF, Hannon GJ. Nature 2004;432:231-5. [PubMed: 15531879]

23. Gregory RI, Yan KP, Amuthan G, Chendrimada T, Doratotaj B, et al. Nature 2004;432:235-40. [PubMed: 15531877]

24. Han J, Lee Y, Yeom KH, Nam JW, Heo I, et al. Cell 2006;125:887-901. [PubMed: 16751099]

25. Okamura K, Hagen JW, Duan H, Tyler DM, Lai EC. Cell. 2007

26. Ruby JG, Jan CH, Bartel DP. Nature 2007;448:83-6. [PubMed: 17589500]

27. Berezikov E, Chung WJ, Willis J, Cuppen E, Lai EC. Mol Cell 2007;28:328-36. [PubMed: 17964270]

28. Yi R, Qin Y, Macara IG, Cullen BR. Genes Dev 2003;17:3011-6. [PubMed: 14681208]

29. Lund E, Guttinger S, Calado A, Dahlberg JE, Kutay U. Science 2004;303:95-8. [PubMed: 14631048]

30. Hutvagner G, McLachlan J, Pasquinelli AE, Balint E, Tuschl T, Zamore PD. Science 2001;293:8348. [PubMed: 11452083]

31. Salzman DW, Shubert-Coleman J, Furneaux H. J Biol Chem 2007;282:32773-9. [PubMed: 17724023]

32. Schwarz DS, Hutvagner G, Du T, Xu Z, Aronin N, Zamore PD. Cell 2003;115:199-208. [PubMed: 14567917]

33. Khvorova A, Reynolds A, Jayasena SD. Cell 2003;115:209-16. [PubMed: 14567918]

34. Filipowicz W, Bhattacharyya SN, Sonenberg N. Nat Rev Genet 2008;9:102-14. [PubMed: 18197166]

35. Lim LP, Lau NC, Garrett-Engele P, Grimson A, Schelter JM, et al. Nature 2005;433:769-73.

[PubMed: 15685193] 
36. Bagga S, Bracht J, Hunter S, Massirer K, Holtz J, et al. Cell 2005;122:553-63. [PubMed: 16122423]

37. Kim HK, Lee YS, Sivaprasad U, Malhotra A, Dutta A. J Cell Biol 2006;174:677-87. [PubMed: 16923828]

38. Lee YS, Dutta A. Genes Dev 2007;21:1025-30. [PubMed: 17437991]

39. Liu J, Valencia-Sanchez MA, Hannon GJ, Parker R. Nat Cell Biol 2005;7:719-23. [PubMed: 15937477]

40. Sen GL, Blau HM. Nat Cell Biol 2005;7:633-6. [PubMed: 15908945]

41. Eulalio A, Behm-Ansmant I, Schweizer D, Izaurralde E. Mol Cell Biol 2007;27:3970-81. [PubMed: 17403906]

42. Chu CY, Rana TM. PLoS Biol 2006;4:e210. [PubMed: 16756390]

43. Lewis BP, Shih IH, Jones-Rhoades MW, Bartel DP, Burge CB. Cell 2003;115:787-98. [PubMed: 14697198]

44. Grimson A, Farh KK, Johnston WK, Garrett-Engele P, Lim LP, Bartel DP. Mol Cell 2007;27:91105. [PubMed: 17612493]

45. Kedde M, Strasser MJ, Boldajipour B, Vrielink JA, Slanchev K, et al. Cell 2007;131:1273-86. [PubMed: 18155131]

46. Maziere P, Enright AJ. Drug Discov Today 2007;12:452-8. [PubMed: 17532529]

47. Zhu S, Si ML, Wu H, Mo YY. J Biol Chem 2007;282:14328-36. [PubMed: 17363372]

48. le Sage C, Nagel R, Egan DA, Schrier M, Mesman E, et al. Embo J 2007;26:3699-708. [PubMed: 17627278]

49. Karginov FV, Conaco C, Xuan Z, Schmidt BH, Parker JS, et al. Proc Natl Acad Sci U S A 2007;104:19291-6. [PubMed: 18042700]

50. Lewis BP, Burge CB, Bartel DP. Cell 2005;120:15-20. [PubMed: 15652477]

51. Xie X, Lu J, Kulbokas EJ, Golub TR, Mootha V, et al. Nature 2005;434:338-45. [PubMed: 15735639]

52. Gantier MP, Sadler AJ, Williams BR. Immunol Cell Biol 2007;85:458-62. [PubMed: 17621315]

53. Calame K. Immunity 2007;27:825-7. [PubMed: 18093533]

54. Poy MN, Eliasson L, Krutzfeldt J, Kuwajima S, Ma X, et al. Nature 2004;432:226-30. [PubMed: 15538371]

55. Greco SJ, Rameshwar P. Proc Natl Acad Sci U S A 2007;104:15484-9. [PubMed: 17855557]

56. Cheng HY, Papp JW, Varlamova O, Dziema H, Russell B, et al. Neuron 2007;54:813-29. [PubMed: 17553428]

57. Jopling CL, Yi M, Lancaster AM, Lemon SM, Sarnow P. Science 2005;309:1577-81. [PubMed: 16141076]

58. Tazawa H, Tsuchiya N, Izumiya M, Nakagama H. Proc Natl Acad Sci U S A 2007;104:15472-7. [PubMed: 17875987]

59. Johnson CD, Esquela-Kerscher A, Stefani G, Byrom M, Kelnar K, et al. Cancer Res 2007;67:771322. [PubMed: 17699775]

60. Bommer GT, Gerin I, Feng Y, Kaczorowski AJ, Kuick R, et al. Curr Biol 2007;17:1298-307. [PubMed: 17656095]

61. Chang TC, Wentzel EA, Kent OA, Ramachandran K, Mullendore M, et al. Mol Cell 2007;26:74552. [PubMed: 17540599]

62. He L, He X, Lim LP, de Stanchina E, Xuan Z, et al. Nature. 2007

63. Calin GA, Dumitru CD, Shimizu M, Bichi R, Zupo S, et al. Proc Natl Acad Sci U S A 2002;99:155249. [PubMed: 12434020]

64. Lu J, Getz G, Miska EA, Alvarez-Saavedra E, Lamb J, et al. Nature 2005;435:834-8. [PubMed: 15944708]

65. Calin GA, Liu CG, Sevignani C, Ferracin M, Felli N, et al. Proc Natl Acad Sci U S A 2004;101:1175560. [PubMed: 15284443]

66. Porkka KP, Pfeiffer MJ, Waltering KK, Vessella RL, Tammela TL, Visakorpi T. Cancer Res 2007;67:6130-5. [PubMed: 17616669]

67. Visone R, Pallante P, Vecchione A, Cirombella R, Ferracin M, et al. Oncogene. 2007

Annu Rev Pathol. Author manuscript; available in PMC 2010 January 1. 
68. Gaur A, Jewell DA, Liang Y, Ridzon D, Moore JH, et al. Cancer Res 2007;67:2456-68. [PubMed: 17363563]

69. Chen Y, Stallings RL. Cancer Res 2007;67:976-83. [PubMed: 17283129]

70. Kumar MS, Lu J, Mercer KL, Golub TR, Jacks T. Nat Genet 2007;39:673-7. [PubMed: 17401365]

71. Calin GA, Sevignani C, Dumitru CD, Hyslop T, Noch E, et al. Proc Natl Acad Sci U S A 2004;101:2999-3004. [PubMed: 14973191]

72. Sevignani C, Calin GA, Nnadi SC, Shimizu M, Davuluri RV, et al. Proc Natl Acad Sci U S A 2007;104:8017-22. [PubMed: 17470785]

73. Zhang L, Huang J, Yang N, Greshock J, Megraw MS, et al. Proc Natl Acad Sci U S A 2006;103:913641. [PubMed: 16754881]

74. Tagawa H, Karube K, Tsuzuki S, Ohshima K, Seto M. Cancer Sci 2007;98:1482-90. [PubMed: 17608773]

75. Rinaldi A, Poretti G, Kwee I, Zucca E, Catapano CV, et al. Leuk Lymphoma 2007;48:410-2. [PubMed: 17325905]

76. Welch C, Chen Y, Stallings RL. Oncogene 2007;26:5017-22. [PubMed: 17297439]

77. Hayashita Y, Osada H, Tatematsu Y, Yamada H, Yanagisawa K, et al. Cancer Res 2005;65:962832. [PubMed: 16266980]

78. Tagawa H, Seto M. Leukemia 2005;19:2013-6. [PubMed: 16167061]

79. Lehmann U, Hasemeier B, Christgen M, Muller M, Romermann D, et al. J Pathol. 2007

80. Lujambio A, Ropero S, Ballestar E, Fraga MF, Cerrato C, et al. Cancer Res 2007;67:1424-9. [PubMed: 17308079]

81. Scott GK, Mattie MD, Berger CE, Benz SC, Benz CC. Cancer Res 2006;66:1277-81. [PubMed: 16452179]

82. Fabbri M, Garzon R, Cimmino A, Liu Z, Zanesi N, et al. Proc Natl Acad Sci U S A 2007;104:1580510. [PubMed: 17890317]

83. Shah YM, Morimura K, Yang Q, Tanabe T, Takagi M, Gonzalez FJ. Mol Cell Biol 2007;27:423847. [PubMed: 17438130]

84. Mott JL, Kobayashi S, Bronk SF, Gores GJ. Oncogene 2007;26:6133-40. [PubMed: 17404574]

85. Kluiver J, van den Berg A, de Jong D, Blokzij1 T, Harms G, et al. Oncogene 2007;26:3769-76. [PubMed: 17173072]

86. Lee EJ, Baek M, Gusev Y, Brackett DJ, Nuovo GJ, Schmittgen TD. Rna 2007;14:35-42. [PubMed: 18025253]

87. Obernosterer G, Leuschner PJ, Alenius M, Martinez J. Rna 2006;12:1161-7. [PubMed: 16738409]

88. Michael MZ, SM OC, van Holst Pellekaan NG, Young GP, James RJ. Mol Cancer Res 2003;1:88291. [PubMed: 14573789]

89. Lu Y, Thomson JM, Wong HY, Hammond SM, Hogan BL. Dev Biol 2007;310:442-53. [PubMed: 17765889]

90. Mineno J, Okamoto S, Ando T, Sato M, Chono H, et al. Nucleic Acids Res 2006;34:1765-71. [PubMed: 16582102]

91. Loffler D, Brocke-Heidrich K, Pfeifer G, Stocsits C, Hackermuller J, et al. Blood 2007;110:1330-3. [PubMed: 17496199]

92. Thomson JM, Newman M, Parker JS, Morin-Kensicki EM, Wright T, Hammond SM. Genes Dev 2006;20:2202-7. [PubMed: 16882971]

93. Blenkiron C, Goldstein LD, Thorne NP, Spiteri I, Chin SF, et al. Genome Biol 2007;8:R214. [PubMed: 17922911]

94. Chiosea S, Jelezcova E, Chandran U, Luo J, Mantha G, et al. Cancer Res 2007;67:2345-50. [PubMed: 17332367]

95. Muralidhar B, Goldstein LD, Ng G, Winder DM, Palmer RD, et al. J Pathol 2007;212:368-77. [PubMed: 17471471]

96. Karube Y, Tanaka H, Osada H, Tomida S, Tatematsu Y, et al. Cancer Sci 2005;96:111-5. [PubMed: 15723655] 
97. Nakamura T, Canaani E, Croce CM. Proc Natl Acad Sci U S A 2007;104:10980-5. [PubMed: 17581865]

98. Johnson SM, Grosshans H, Shingara J, Byrom M, Jarvis R, et al. Cell 2005;120:635-47. [PubMed: 15766527]

99. Yang J, Zhou F, Xu T, Deng H, Ge YY, et al. Mutat Res. 2007

100. He H, Jazdzewski K, Li W, Liyanarachchi S, Nagy R, et al. Proc Natl Acad Sci U S A 2005;102:19075-80. [PubMed: 16365291]

101. Diederichs S, Haber DA. Cancer Res 2006;66:6097-104. [PubMed: 16778182]

102. Yu Z, Li Z, Jolicoeur N, Zhang L, Fortin Y, et al. Nucleic Acids Res 2007;35:4535-41. [PubMed: 17584784]

103. Abelson JF, Kwan KY, O’Roak BJ, Baek DY, Stillman AA, et al. Science 2005;310:317-20. [PubMed: 16224024]

104. Clop A, Marcq F, Takeda H, Pirottin D, Tordoir X, et al. Nat Genet 2006;38:813-8. [PubMed: 16751773]

105. Adams BD, Furneaux H, White BA. Mol Endocrinol 2007;21:1132-47. [PubMed: 17312270]

106. Mayr C, Hemann MT, Bartel DP. Science 2007;315:1576-9. [PubMed: 17322030]

107. Laneve P, Di Marcotullio L, Gioia U, Fiori ME, Ferretti E, et al. Proc Natl Acad Sci U S A 2007;104:7957-62. [PubMed: 17483472]

108. Nagy E, Maquat LE. Trends Biochem Sci 1998;23:198-9. [PubMed: 9644970]

109. Vasudevan S, Tong Y, Steitz JA. Science 2007;318:1931-4. [PubMed: 18048652]

110. Pfeffer S, Zavolan M, Grasser FA, Chien M, Russo JJ, et al. Science 2004;304:734-6. [PubMed: 15118162]

111. Lo AK, To KF, Lo KW, Lung RW, Hui JW, et al. Proc Natl Acad Sci U S A. 2007

112. Samols MA, Skalsky RL, Maldonado AM, Riva A, Lopez MC, et al. PLoS Pathog 2007;3:e65. [PubMed: 17500590]

113. Clurman BE, Hayward WS. Mol Cell Biol 1989;9:2657-64. [PubMed: 2548084]

114. Makunin IV, Pheasant M, Simons C, Mattick JS. PLoS ONE 2007;2:e1133. [PubMed: 17989771]

115. Cui JW, Li YJ, Sarkar A, Brown J, Tan YH, et al. Blood 2007;110:2631-40. [PubMed: 17586726]

116. Landais S, Landry S, Legault P, Rassart E. Cancer Res 2007;67:5699-707. [PubMed: 17575136]

117. Slape C, Hartung H, Lin YW, Bies J, Wolff L, Aplan PD. Cancer Res 2007;67:5148-55. [PubMed: 17545593]

118. Lum AM, Wang BB, Li L, Channa N, Bartha G, Wabl M. Retrovirology 2007;4:5. [PubMed: 17442096]

119. He L, Thomson JM, Hemann MT, Hernando-Monge E, Mu D, et al. Nature 2005;435:828-33. [PubMed: 15944707]

120. Ota A, Tagawa H, Karnan S, Tsuzuki S, Karpas A, et al. Cancer Res 2004;64:3087-95. [PubMed: 15126345]

121. Matsubara H, Takeuchi T, Nishikawa E, Yanagisawa K, Hayashita Y, et al. Oncogene 2007;26:6099-105. [PubMed: 17384677]

122. Volinia S, Calin GA, Liu CG, Ambs S, Cimmino A, et al. Proc Natl Acad Sci U S A 2006;103:225761. [PubMed: 16461460]

123. O’Donnell KA, Wentzel EA, Zeller KI, Dang CV, Mendell JT. Nature 2005;435:839-43. [PubMed: 15944709]

124. Schulte JH, Horn S, Otto T, Samans B, Heukamp LC, et al. Int J Cancer. 2007

125. Woods K, Thomson JM, Hammond SM. J Biol Chem 2007;282:2130-4. [PubMed: 17135268]

126. Sylvestre Y, De Guire V, Querido E, Mukhopadhyay UK, Bourdeau V, et al. J Biol Chem 2007;282:2135-43. [PubMed: 17135249]

127. Costinean S, Zanesi N, Pekarsky Y, Tili E, Volinia S, et al. Proc Natl Acad Sci U S A 2006;103:70249. [PubMed: 16641092]

128. Kluiver J, Poppema S, de Jong D, Blokzij1 T, Harms G, et al. J Pathol 2005;207:243-9. [PubMed: 16041695] 
129. Eis PS, Tam W, Sun L, Chadburn A, Li Z, et al. Proc Natl Acad Sci U S A 2005;102:3627-32. [PubMed: 15738415]

130. Metzler M, Wilda M, Busch K, Viehmann S, Borkhardt A. Genes Chromosomes Cancer 2004;39:167-9. [PubMed: 14695998]

131. O’Connell RM, Taganov KD, Boldin MP, Cheng G, Baltimore D. Proc Natl Acad Sci U S A 2007;104:1604-9. [PubMed: 17242365]

132. Shell S, Park SM, Radjabi AR, Schickel R, Kistner EO, et al. Proc Natl Acad Sci U S A 2007;104:11400-5. [PubMed: 17600087]

133. Dutta KK, Zhong Y, Liu YT, Yamada T, Akatsuka S, et al. Cancer Sci. 2007

134. Meng F, Henson R, Wehbe-Janek H, Ghoshal K, Jacob ST, Patel T. Gastroenterology 2007;133:64758. [PubMed: 17681183]

135. Gillies JK, Lorimer IA. Cell Cycle 2007;6:2005-9. [PubMed: 17721077]

136. Galardi S, Mercatelli N, Giorda E, Massalini S, Frajese GV, et al. J Biol Chem 2007;282:2371624. [PubMed: 17569667]

137. Tarasov V, Jung P, Verdoodt B, Lodygin D, Epanchintsev A, et al. Cell Cycle 2007;6:1586-93. [PubMed: 17554199]

138. Linsley PS, Schelter J, Burchard J, Kibukawa M, Martin MM, et al. Mol Cell Biol 2007;27:224052. [PubMed: 17242205]

139. Mertens-Talcott SU, Chintharlapalli S, Li X, Safe S. Cancer Res 2007;67:11001-11. [PubMed: 18006846]

140. Cimmino A, Calin GA, Fabbri M, Iorio MV, Ferracin M, et al. Proc Natl Acad Sci U S A 2005;102:13944-9. [PubMed: 16166262]

141. Raver-Shapira N, Marciano E, Meiri E, Spector Y, Rosenfeld N, et al. Mol Cell 2007;26:731-43. [PubMed: 17540598]

142. Xi Y, Shalgi R, Fodstad O, Pilpel Y, Ju J. Clin Cancer Res 2006;12:2014-24. [PubMed: 16609010]

143. Corney DC, Flesken-Nikitin A, Godwin AK, Wang W, Nikitin AY. Cancer Res 2007;67:8433-8. [PubMed: 17823410]

144. Scott GK, Goga A, Bhaumik D, Berger CE, Sullivan CS, Benz CC. J Biol Chem 2007;282:1479_ 86. [PubMed: 17110380]

145. Asangani IA, Rasheed SA, Nikolova DA, Leupold JH, Colburn NH, et al. Oncogene. 2007

146. Ma L, Teruya-Feldstein J, Weinberg RA. Nature. 2007

147. Dews M, Homayouni A, Yu D, Murphy D, Sevignani C, et al. Nat Genet 2006;38:1060-5. [PubMed: 16878133]

148. Lee DY, Deng Z, Wang CH, Yang BB. Proc Natl Acad Sci U S A 2007;104:20350-5. [PubMed: 18077375]

149. Hebert C, Norris K, Scheper MA, Nikitakis N, Sauk JJ. Mol Cancer 2007;6:5. [PubMed: 17222355]

150. Kulshreshtha R, Ferracin M, Wojcik SE, Garzon R, Alder H, et al. Mol Cell Biol 2007;27:1859-67. [PubMed: 17194750]

151. Marsit CJ, Eddy K, Kelsey KT. Cancer Res 2006;66:10843-8. [PubMed: 17108120]

152. Kutay H, Bai S, Datta J, Motiwala T, Pogribny I, et al. J Cell Biochem 2006;99:671-8. [PubMed: 16924677]

153. Tang F, Hajkova P, Barton SC, Lao K, Surani MA. Nucleic Acids Res 2006;34:e9. [PubMed: 16434699]

154. Kim do N, Chae HS, Oh ST, Kang JH, Park CH, et al. J Virol 2007;81:1033-6. [PubMed: 17079300]

155. Xi Y, Nakajima G, Gavin E, Morris CG, Kudo K, et al. Rna 2007;13:1668-74. [PubMed: 17698639]

156. Lawrie CH, Soneji S, Marafioti T, Cooper CD, Palazzo S, et al. Int J Cancer 2007;121:1156-61. [PubMed: 17487835]

157. Zhang HH, Wang XJ, Li GX, Yang E, Yang NM. World J Gastroenterol 2007;13:2883-8. [PubMed: 17569129]

158. Mattie MD, Benz CC, Bowers J, Sensinger K, Wong L, et al. Mol Cancer 2006;5:24. [PubMed: 16784538] 
159. Pallante P, Visone R, Ferracin M, Ferraro A, Berlingieri MT, et al. Endocr Relat Cancer 2006;13:497-508. [PubMed: 16728577]

160. Szafranska AE, Davison TS, John J, Cannon T, Sipos B, et al. Oncogene 2007;26:4442-52. [PubMed: 17237814]

161. Hutvagner G, Zamore PD. Science 2002;297:2056-60. [PubMed: 12154197]

162. Hossain A, Kuo MT, Saunders GF. Mol Cell Biol 2006;26:8191-201. [PubMed: 16940181]

163. Weiler J, Hunziker J, Hall J. Gene Ther 2006;13:496-502. [PubMed: 16195701]

164. Krutzfeldt J, Rajewsky N, Braich R, Rajeev KG, Tuschl T, et al. Nature 2005;438:685-9. [PubMed: 16258535]

165. Si ML, Zhu S, Wu H, Lu Z, Wu F, Mo YY. Oncogene 2007;26:2799-803. [PubMed: 17072344]

166. Elmen J, Lindow M, Silahtaroglu A, Bak M, Christensen M, et al. Nucleic Acids Res. 2007

167. Cullen BR. Nat Genet 2005;37:1163-5. [PubMed: 16254559]

168. Ebert MS, Neilson JR, Sharp PA. Nat Methods 2007;4:721-6. [PubMed: 17694064]

169. Franco-Zorrilla JM, Valli A, Todesco M, Mateos I, Puga MI, et al. Nat Genet 2007;39:1033-7. [PubMed: 17643101]

170. Orom UA, Kauppinen S, Lund AH. Gene 2006;372:137-41. [PubMed: 16503100]

171. Krutzfeldt J, Kuwajima S, Braich R, Rajeev KG, Pena J, et al. Nucleic Acids Res 2007;35:288592. [PubMed: 17439965]

172. Grimm D, Streetz KL, Jopling CL, Storm TA, Pandey K, et al. Nature 2006;441:537-41. [PubMed: 16724069]

173. Lee YS, Kim HK, Chung S, Kim KS, Dutta A. J Biol Chem 2005;280:16635-41. [PubMed: 15722555]

174. Jing Q, Huang S, Guth S, Zarubin T, Motoyama A, et al. Cell 2005;120:623-34. [PubMed: 15766526]

175. Blower PE, Verducci JS, Lin S, Zhou J, Chung JH, et al. Mol Cancer Ther 2007;6:1483-91. [PubMed: 17483436]

176. Meng F, Henson R, Lang M, Wehbe H, Maheshwari S, et al. Gastroenterology 2006;130:2113-29. [PubMed: 16762633]

177. Corsten MF, Miranda R, Kasmieh R, Krichevsky AM, Weissleder R, Shah K. Cancer Res 2007;67:8994-9000. [PubMed: 17908999]

178. Lau NC. Curr Protoc Mol Biol 2008:7. [PubMed: 18231982]Chapter 26: Unit26

179. Kapranov P, Willingham AT, Gingeras TR. Nat Rev Genet 2007;8:413-23. [PubMed: 17486121]

180. Kapranov P, Cheng J, Dike S, Nix DA, Duttagupta R, et al. Science 2007;316:1484-8. [PubMed: 17510325]

181. Caudy AA, Myers M, Hannon GJ, Hammond SM. Genes Dev 2002;16:2491-6. [PubMed: 12368260]

182. Bilen J, Liu N, Bonini NM. Cell Cycle 2006;5:2835-8. [PubMed: 17172864]

183. Perkins DO, Jeffries CD, Jarskog LF, Thomson JM, Woods K, et al. Genome Biol 2007;8:R27. [PubMed: 17326821]

184. Hon LS, Zhang Z. Genome Biol 2007;8:R166. [PubMed: 17697356]

185. Iorio MV, Ferracin M, Liu CG, Veronese A, Spizzo R, et al. Cancer Res 2005;65:7065-70. [PubMed: 16103053]

186. Ozen M, Creighton CJ, Ozdemir M, Ittmann M. Oncogene. 2007

187. Bloomston M, Frankel WL, Petrocca F, Volinia S, Alder H, et al. Jama 2007;297:1901-8. [PubMed: 17473300]

188. Lee EJ, Gusev Y, Jiang J, Nuovo GJ, Lerner MR, et al. Int J Cancer 2007;120:1046-54. [PubMed: 17149698]

189. Roldo C, Missiaglia E, Hagan JP, Falconi M, Capelli P, et al. J Clin Oncol 2006;24:4677-84. [PubMed: 16966691]

190. Yanaihara N, Caplen N, Bowman E, Seike M, Kumamoto K, et al. Cancer Cell 2006;9:189-98. [PubMed: 16530703] 
191. Iorio MV, Visone R, Di Leva G, Donati V, Petrocca F, et al. Cancer Res 2007;67:8699-707. [PubMed: 17875710]

192. Wang T, Zhang X, Obijuru L, Laser J, Aris V, et al. Genes Chromosomes Cancer 2007;46:336-47. [PubMed: 17243163]

193. Gramantieri L, Ferracin M, Fornari F, Veronese A, Sabbioni S, et al. Cancer Res 2007;67:6092-9. [PubMed: 17616664]

194. Murakami Y, Yasuda T, Saigo K, Urashima T, Toyoda H, et al. Oncogene 2006;25:2537-45. [PubMed: 16331254]

195. Weber F, Teresi RE, Broelsch CE, Frilling A, Eng C. J Clin Endocrinol Metab 2006;91:3584-91. [PubMed: 16822819]

196. Lanza G, Ferracin M, Gafa R, Veronese A, Spizzo R, et al. Mol Cancer 2007;6:54. [PubMed: 17716371]

197. Bandres E, Cubedo E, Agirre X, Malumbres R, Zarate R, et al. Mol Cancer 2006;5:29. [PubMed: 16854228]

198. Bottoni A, Zatelli MC, Ferracin M, Tagliati F, Piccin D, et al. J Cell Physiol 2007;210:370-7. [PubMed: 17111382]

199. Ciafre SA, Galardi S, Mangiola A, Ferracin M, Liu CG, et al. Biochem Biophys Res Commun 2005;334:1351-8. [PubMed: 16039986]

200. Mi S, Lu J, Sun M, Li Z, Zhang H, et al. Proc Natl Acad Sci U S A 2007;104:19971-6. [PubMed: 18056805]

201. Fulci V, Chiaretti S, Goldoni M, Azzalin G, Carucci N, et al. Blood 2007;109:4944-51. [PubMed: 17327404]

202. Pekarsky Y, Santanam U, Cimmino A, Palamarchuk A, Efanov A, et al. Cancer Res 2006;66:115903. [PubMed: 17178851]

203. Calin GA, Ferracin M, Cimmino A, Di Leva G, Shimizu M, et al. N Engl J Med 2005;353:1793801. [PubMed: 16251535]

204. Subramanian S, Lui WO, Lee CH, Espinosa I, Nielsen TO, et al. Oncogene. 2007

205. Nakajima G, Hayashi K, Xi Y, Kudo K, Uchida K, et al. Cancer Genomics Proteomics 2006;3:31724. [PubMed: 18172508]

206. Sempere LF, Christensen M, Silahtaroglu A, Bak M, Heath CV, et al. Cancer Res 2007;67:1161220. [PubMed: 18089790]

207. Takamizawa J, Konishi H, Yanagisawa K, Tomida S, Osada H, et al. Cancer Res 2004;64:3753-6. [PubMed: 15172979]

208. Lui WO, Pourmand N, Patterson BK, Fire A. Cancer Res 2007;67:6031-43. [PubMed: 17616659]

209. Chan JA, Krichevsky AM, Kosik KS. Cancer Res 2005;65:6029-33. [PubMed: 16024602]

210. Tsuchiya Y, Nakajima M, Takagi S, Taniya T, Yokoi T. Cancer Res 2006;66:9090-8. [PubMed: 16982751]

211. Shi XB, Xue L, Yang J, Ma AH, Zhao J, et al. Proc Natl Acad Sci U S A 2007;104:19983-8. [PubMed: 18056640]

212. Akao Y, Nakagawa Y, Kitade Y, Kinoshita T, Naoe T. Cancer Sci. 2007

213. Voorhoeve PM, le Sage C, Schrier M, Gillis AJ, Stoop H, et al. Cell 2006;124:1169-81. [PubMed: 16564011]

214. Bottoni A, Piccin D, Tagliati F, Luchin A, Zatelli MC, degli Uberti EC. J Cell Physiol 2005;204:2805. [PubMed: 15648093]

215. He L, He X, Lim LP, de Stanchina E, Xuan Z, et al. Nature 2007;447:1130-4. [PubMed: 17554337]

216. Meng F, Henson R, Wehbe-Janek H, Smith H, Ueno Y, Patel T. J Biol Chem 2007;282:8256-64. [PubMed: 17220301]

217. Saito Y, Liang G, Egger G, Friedman JM, Chuang JC, et al. Cancer Cell 2006;9:435-43. [PubMed: 16766263]

218. Brueckner B, Stresemann C, Kuner R, Mund C, Musch T, et al. Cancer Res 2007;67:1419-23. [PubMed: 17308078] 
219. Venturini L, Battmer K, Castoldi M, Schultheis B, Hochhaus A, et al. Blood 2007;109:4399-405. [PubMed: 17284533] 


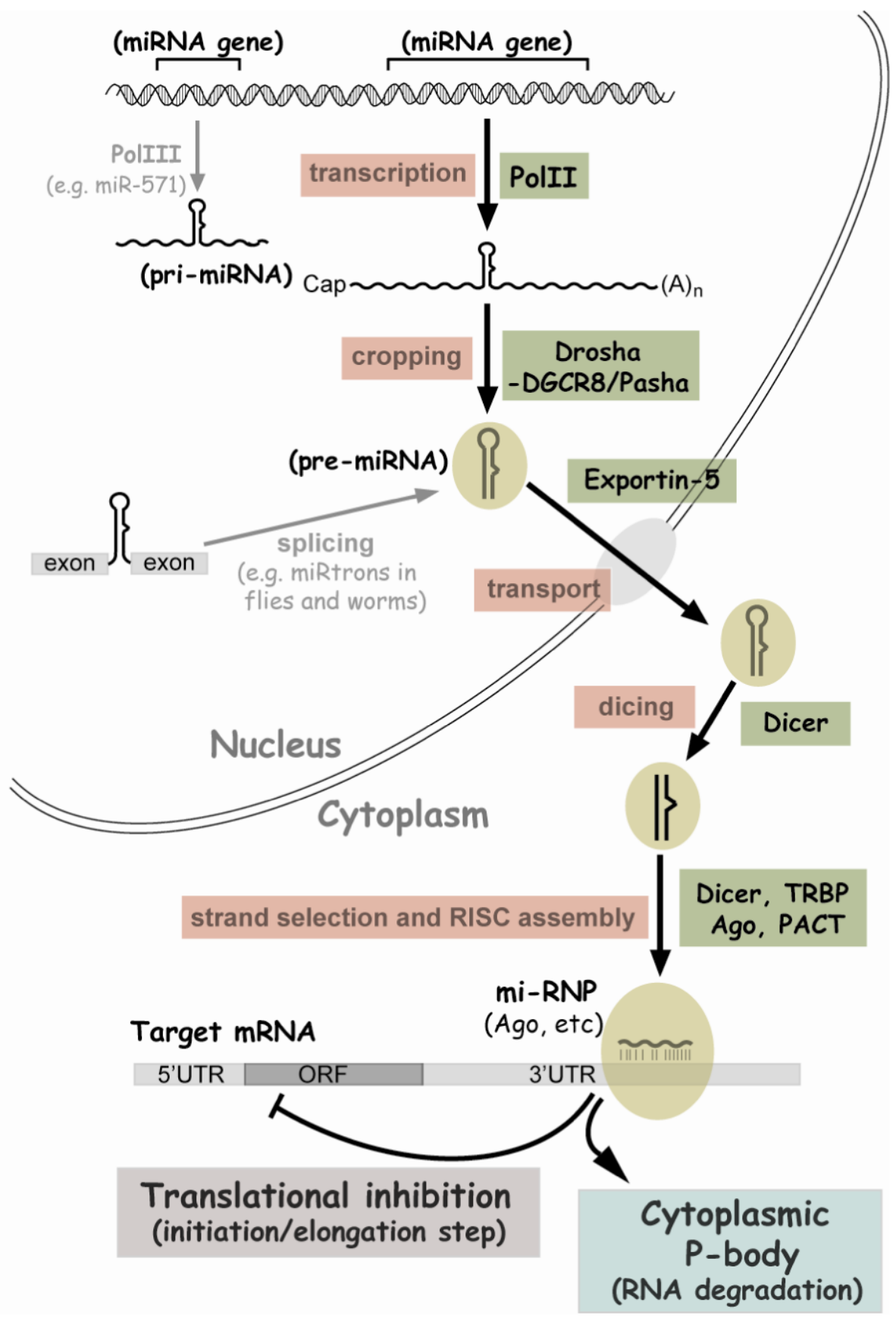

Figure 1. Pathways of miRNA biogenesis and action

Black lines indicate the canonical pathway, with minor pathways (grey lines) also depicted 
MiRNA gene 0000000000000000000000000

\section{Epigenetic regulation \\ - CpG methylation \\ - histone modification}

Transcription factor Myc, E2Fs, p53, BCR-ABL, Twist, NF-KB, ER- $\alpha, A R$, STAT3, ....

\section{Genomic abnomalities \\ gene amplification/deletion}

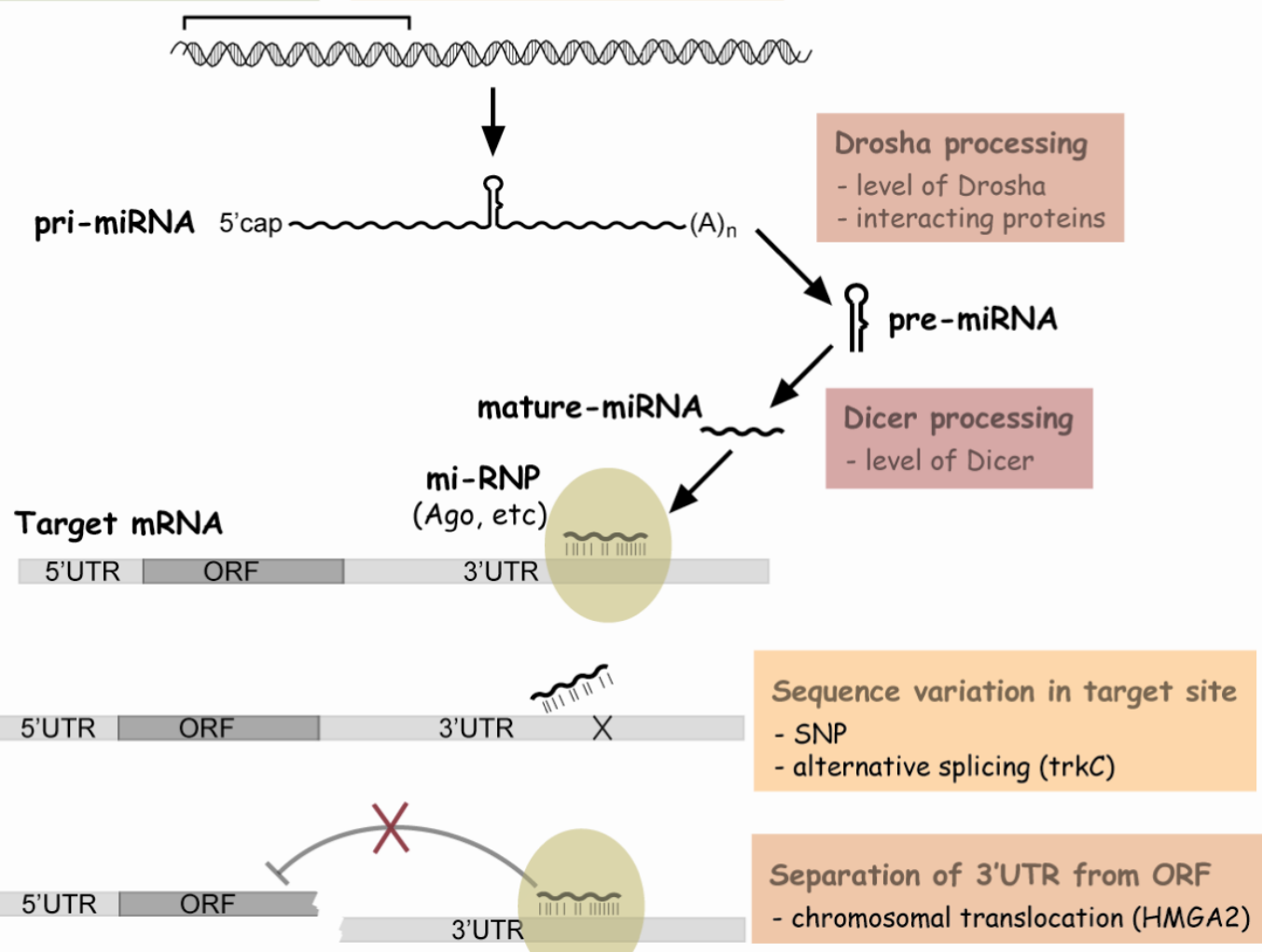

Figure 2. Various mechanisms for deregulation of miRNA expression or function 
$\operatorname{chr} 13 q 31.3$

100000000000000000000000000000000000000

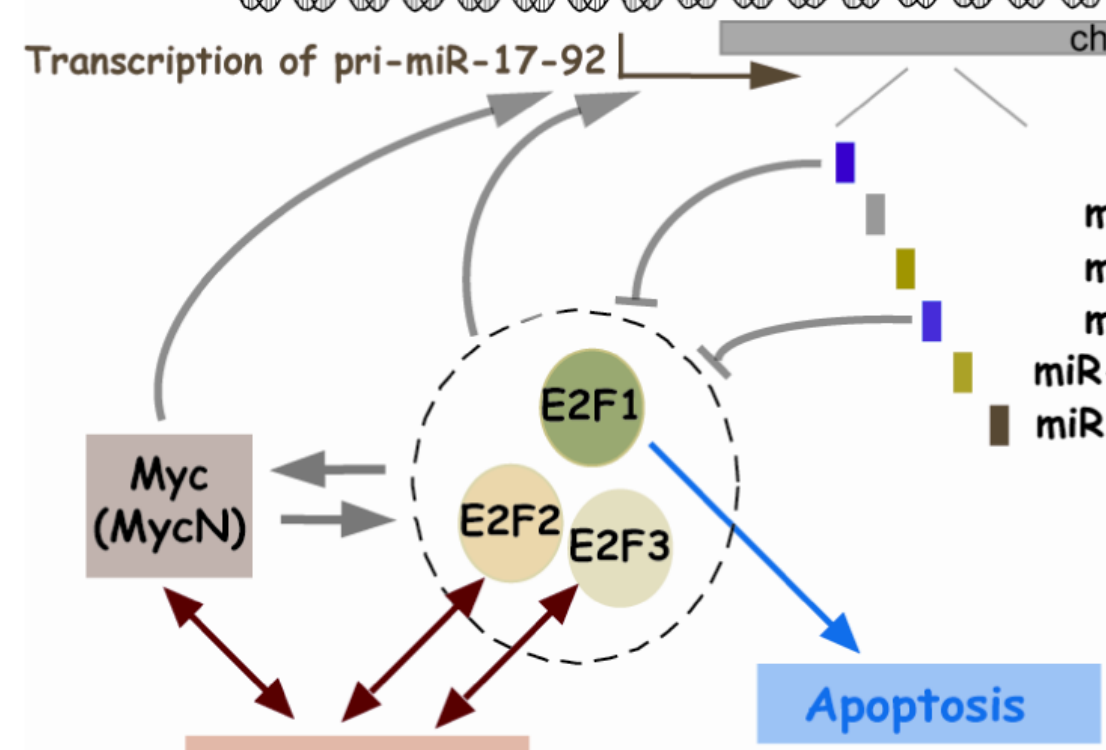

\section{Proliferation}

Figure 3. miR-17-92 pathway 


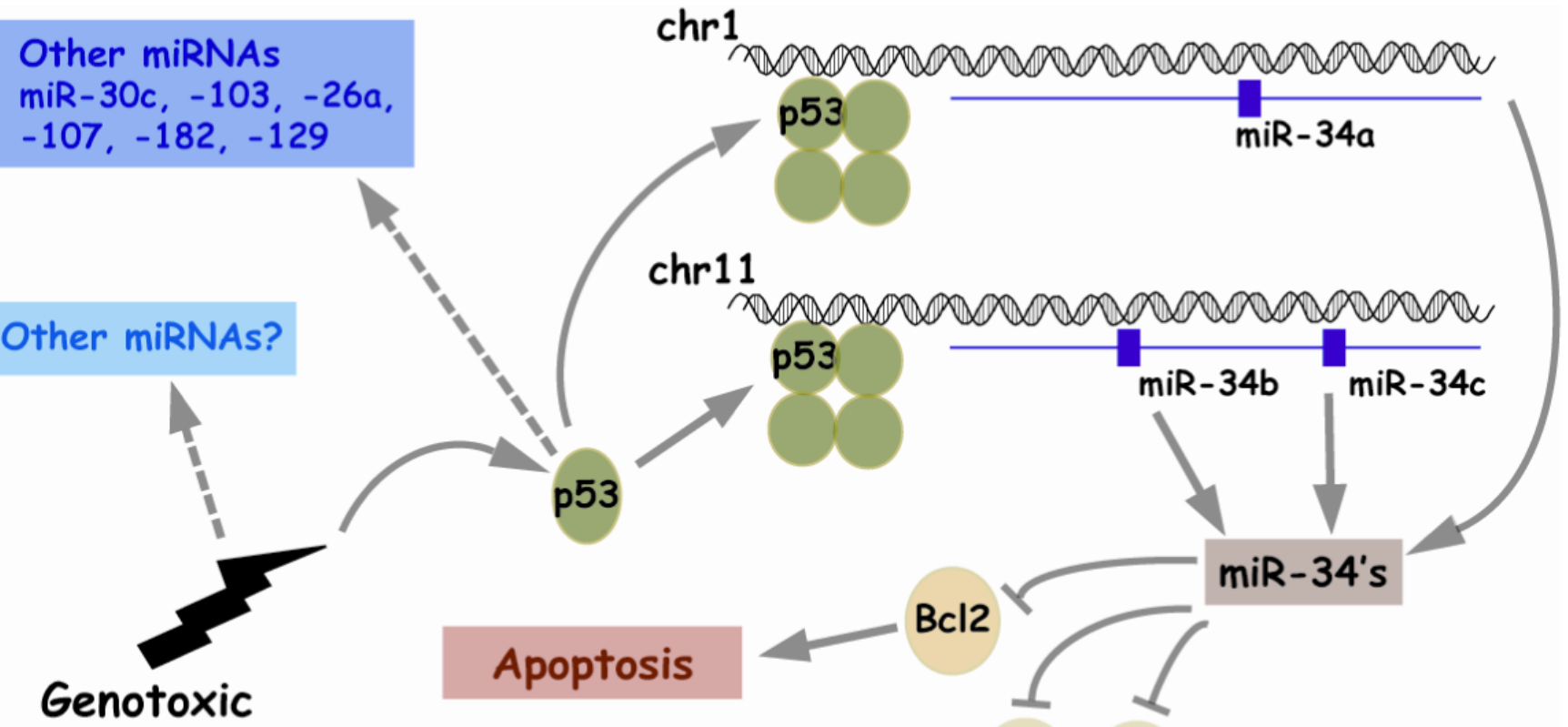
stress

\section{Cell cycle arrest $\longleftarrow$ Cdk4 MET}

\section{Senescence}

Figure 4. p53 and miR-34 pathway 
列

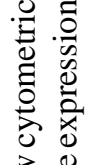

Z

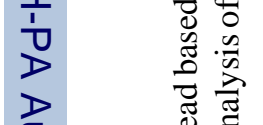

产

흘

莺

হె

कू

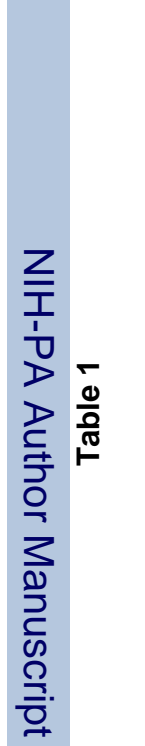

ô

는

官

롱

.0

导

ర్ర

氙

兽葛

离

के ?

告

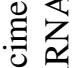

¿

का पै

氜

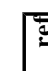

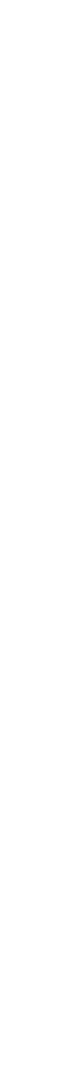

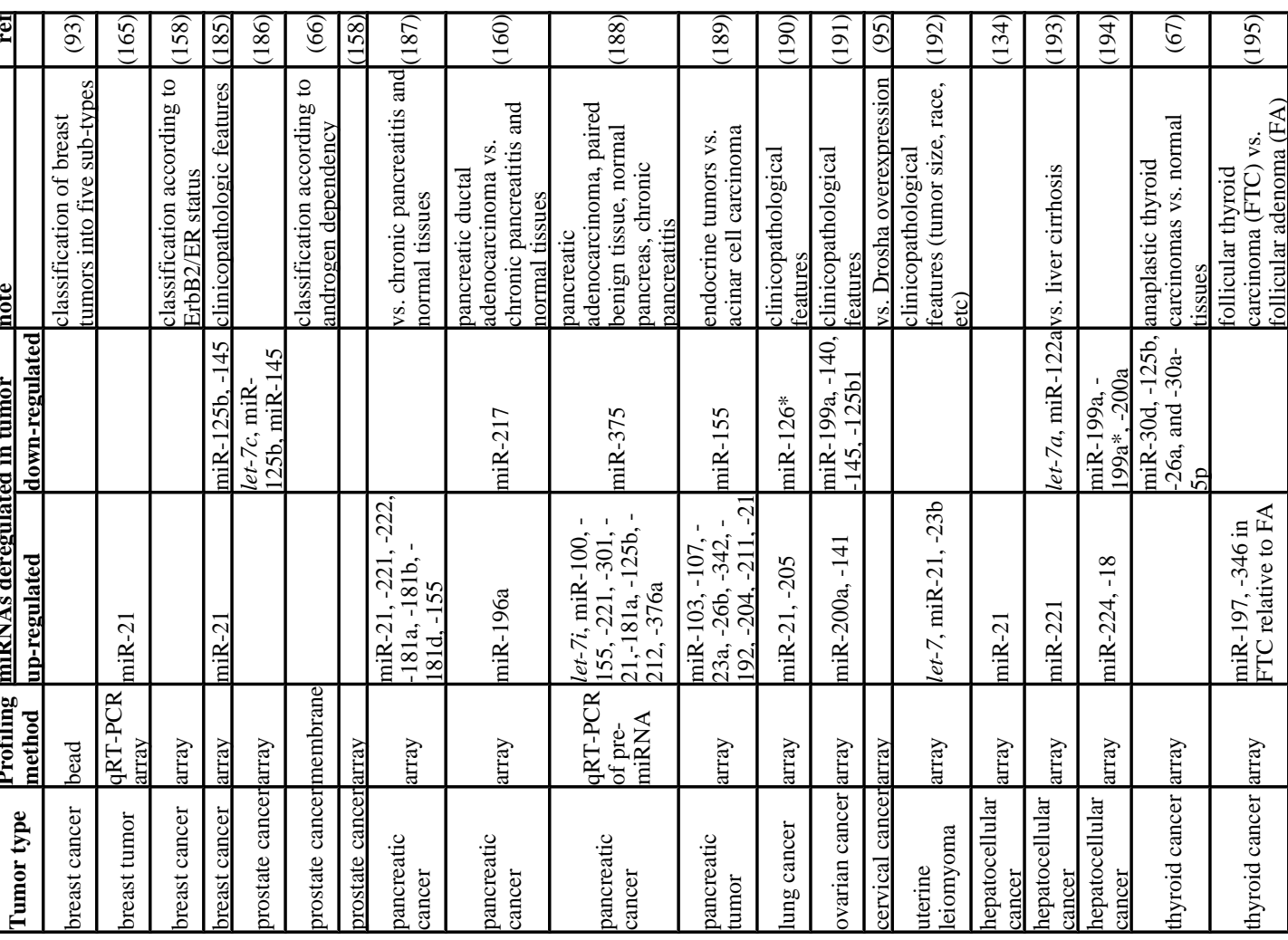

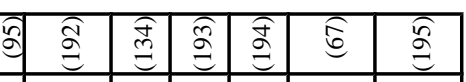

Annu Rev Pathol. Author manuscript; available in PMC 2010 January 1. 


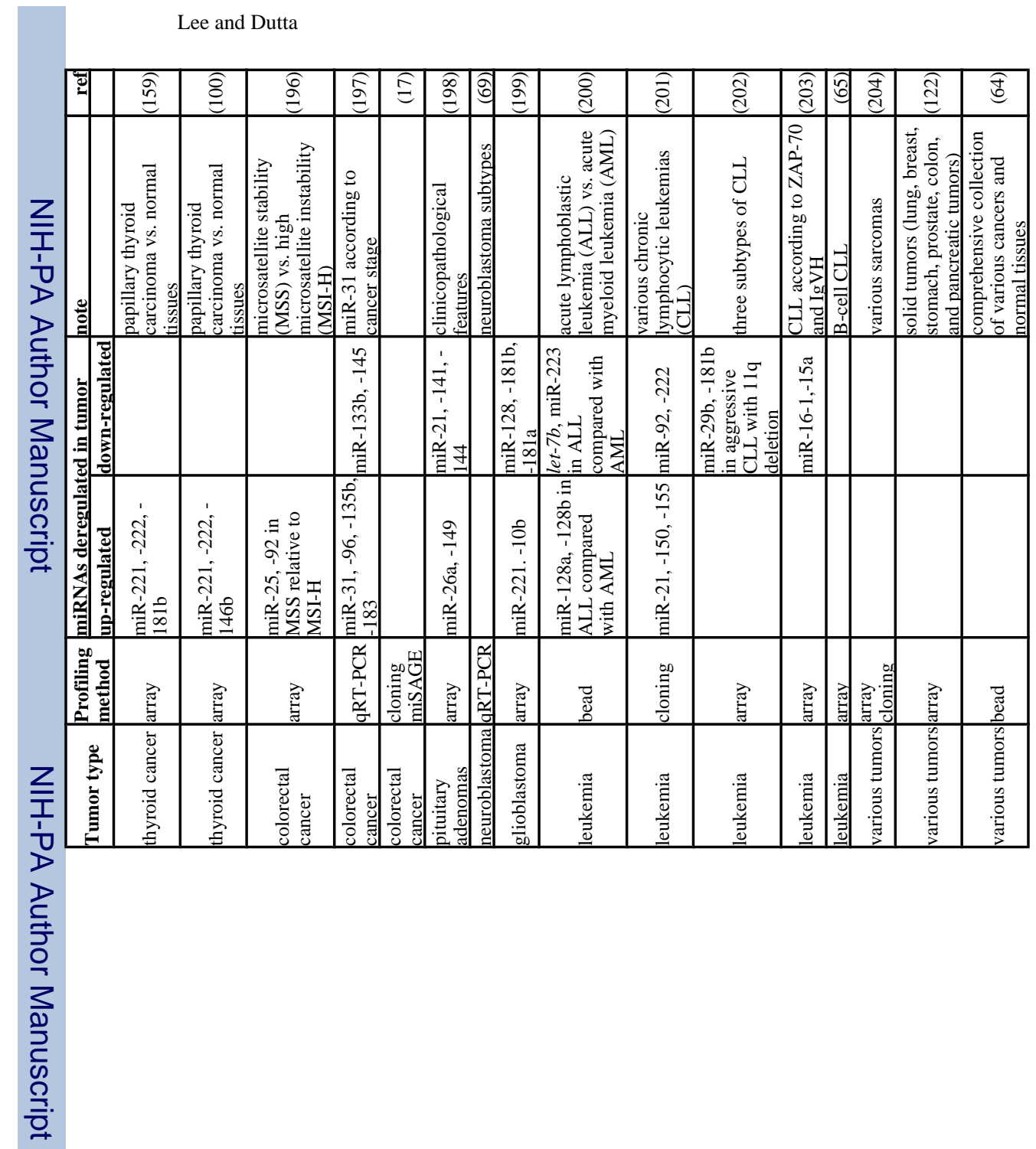

Annu Rev Pathol. Author manuscript; available in PMC 2010 January 1. 
Table 2

miRNAs up- or down-regulated in various tumors relative to normal tissues

\begin{tabular}{|c|c|c|c|}
\hline miRNA & up/dov & cancer & ref \\
\hline & up & colon cancer & $(205)$ \\
\hline & down & breast cancer & $(206)$ \\
\hline & down & prostate cancer & (186) \\
\hline & down & hepatocellular cancer & (193) \\
\hline & down & gastric tumor & (157) \\
\hline Let-1 & up & uterine leiomyoma & (192) \\
\hline & up & pancreatic cancer & (188) \\
\hline & up & hepatocelluar carcinoma & $(152)$ \\
\hline & down & lung cancer & (98) \\
\hline & down & lung cancer & (207) \\
\hline & down & breast cancer & (79) \\
\hline miR-9 & up & breast cancer & (146) \\
\hline & down & neuroblastoma & (107) \\
\hline miP $10 \mathrm{~h}$ & up & breast cancer & (146) \\
\hline mIK-100 & up & glioblastoma & (199) \\
\hline $\operatorname{miR} 17-5 n$ & up & neuroblastoma & $(124)$ \\
\hline [IIIK-1/-5p & down & breast cancer & $(162)$ \\
\hline miR-18 & up & hepatocellular carcinoma & (194) \\
\hline & up & breast cancer & (206) \\
\hline & up & colorectal cancer & (145) \\
\hline & up & ovarian cancer & $(191)$ \\
\hline & up & hepatocellular cancer & $(134)$ \\
\hline & up & cervical cancer & $(208)$ \\
\hline & up & pancreatic cancer & $(187)$ \\
\hline & up & chronic lymphocytic leukemia & $(201)$ \\
\hline & up & uterine leiomyoma & $(192)$ \\
\hline $\operatorname{miR}-21$ & up & pancreatic cancer & (188) \\
\hline & down & pituitary adenomas & $(198)$ \\
\hline & up & breast tumor & $(165)$ \\
\hline & up & pancreatic tumor & (189) \\
\hline & up & hepatocelluar carcinoma & $(152)$ \\
\hline & up & cholangiocarcinoma & (176) \\
\hline & up & lung cancer & (190) \\
\hline & up & breast cancer & $(185)$ \\
\hline & up & glioblastoma & (209) \\
\hline miR-23a & up & pancreatic tumor & $(189)$ \\
\hline miR-23b & up & uterine leiomyoma & $(192)$ \\
\hline miR-23 & up & hepatocelluar carcinoma & $(152)$ \\
\hline miR-26a & down & thyroid cancer & $(67)$ \\
\hline miR-26b & up & pancreatic tumor & (189) \\
\hline $\operatorname{miR}-27 \mathrm{a}$ & up & breast cancer & $(139)$ \\
\hline miR-27b & down & breast cancer & (210) \\
\hline miR-29s & down & cholangiocarcinoma & $(84)$ \\
\hline miR-30a & down & thyroid cancer & (67) \\
\hline miR-30d & down & thyroid cancer & $(67)$ \\
\hline miR-31 & up & colorectal cancer & (197) \\
\hline & down & lung cancer & $(60)$ \\
\hline & down & neuroblastoma & $(76)$ \\
\hline $\mathrm{miR}-34 \mathrm{~s}$ & down & pancreatic cancers & $(61)$ \\
\hline $\mid 1 m-540$ & up & renal cell carcinoma & $(133)$ \\
\hline & up & colon cancers & $(58)$ \\
\hline & up & hepatocellular carcinoma & $(134)$ \\
\hline miR_9? & up & neuroblastoma & $(124)$ \\
\hline IIIIN-92 & down & chronic lymphocytic leukemia & $(201)$ \\
\hline miR-96 & up & colorectal cancer & (197) \\
\hline miR-100 & up & pancreatic cancer & (188) \\
\hline miR-103 & up & pancreatic tumor & (189) \\
\hline miR-107 & up & pancreatic tumor & (188) \\
\hline miR-122a & down & hepatocellular cancer & $(193)$ \\
\hline miR-122 & down & hepatocelluar carcinoma & $(152)$ \\
\hline miR-124a & down & colon cancer, lung cancer & $(80)$ \\
\hline miR-125a & down & neuroblastoma & $(107)$ \\
\hline & up & prostate cancer & (211) \\
\hline $\mathrm{miR}-125 \mathrm{~b}$ & down & prostate cancer & (186) \\
\hline $\mid 111+-1250$ & down & ovarian cancer & $(191)$ \\
\hline & down & thyroid cancer & {$[(67)$} \\
\hline
\end{tabular}




\begin{tabular}{|c|c|c|c|}
\hline \multirow[t]{4}{*}{ miRNA } & \multicolumn{2}{|c|}{\begin{tabular}{l|l} 
up/down cancer \\
\end{tabular}} & \multirow{2}{*}{\begin{tabular}{|r|} 
ref \\
$(107)$ \\
\end{tabular}} \\
\hline & down & neuroblastoma & \\
\hline & up & pancreatic cancer & $(188)$ \\
\hline & down & breast cancer & (185) \\
\hline miR-126* & down & lung cancer & (190) \\
\hline miR-128 & down & glioblastoma & (199) \\
\hline miR-130 & up & hepatocelluar carcinoma & $(152)$ \\
\hline miR-133b & down & colorectal cancer & (197) \\
\hline miR-135b & up & colorectal cancer & (197) \\
\hline miR-140 & down & ovarian cancer & (191) \\
\hline \multirow{2}{*}{ miR-141 } & up & ovarian cancer & (191) \\
\hline & down & pituitary adenomas & (198) \\
\hline \multirow{3}{*}{$\operatorname{miR}-143$} & down & B-cell maligancies & (212) \\
\hline & down & cervical cancer & (208) \\
\hline & down & colorectal neoplasia & $(88)$ \\
\hline miR-144 & down & pituitary adenomas & (198) \\
\hline \multirow[t]{6}{*}{ miR-145 } & down & B-cell maligancies & (212) \\
\hline & down & prostate cancer & (186) \\
\hline & down & ovarian cancer & (191) \\
\hline & down & colorectal cancer & (197) \\
\hline & down & breast cancer & (185) \\
\hline & down & colorectal neoplasia & $(88)$ \\
\hline miR-146b & up & papillary thyroid carcinoma & $(100)$ \\
\hline miR-149 & up & pituitary adenomas & (198) \\
\hline miR-150 & up & chronic lymphocytic leukemia & (201) \\
\hline \multirow{8}{*}{ miR-155 } & up & breast cancer & (146) \\
\hline & up & pancreatic cancer & (187) \\
\hline & up & chronic lymphocytic leukemia & (201) \\
\hline & up & Pancreatic cancer & (188) \\
\hline & down & pancreatic tumor & (189) \\
\hline & up & $\begin{array}{l}\text { Hodgkin's lymphomas, diffuse large B cell lymphoma, primary } \\
\text { mediastinal B cell lymphoma }\end{array}$ & (128) \\
\hline & up & diffuse large B cell lymphoma & (129) \\
\hline & up & Burkitt lymphoma & (130) \\
\hline \multirow{3}{*}{ miR-181a } & up & pancreatic cancer & (187) \\
\hline & up & pancreatic cancer & (188) \\
\hline & down & glioblastoma & (199) \\
\hline \multirow{4}{*}{$\operatorname{miR}-181 \mathrm{~b}$} & up & colon cancer & (205) \\
\hline & up & pancreatic cancer & (187) \\
\hline & up & papillary thyroid carcinoma & (159) \\
\hline & down & glioblastoma & (199) \\
\hline miR-181d & up & pancreatic cancer & (187) \\
\hline miR-183 & up & colorectal cancer & (197) \\
\hline miR-184 & down & neuroblastoma & $(69)$ \\
\hline miR-192 & up & pancreatic tumor & (189) \\
\hline miR-196a & up & pancreatic ductal adenocarcinoma & (160) \\
\hline miR-197 & up & thyroid cancer & (195) \\
\hline \multirow{2}{*}{ miR-199a } & down & ovarian cancer & (191) \\
\hline & down & hepatocellular carcinoma & (194) \\
\hline $\begin{array}{l}\operatorname{miR}- \\
199 a^{*}\end{array}$ & down & hepatocellular carcinoma & (194) \\
\hline \multirow{2}{*}{ miR-200a } & up & ovarian cancer & (191) \\
\hline & down & hepatocellular carcinoma & (194) \\
\hline $\mathrm{miR}-200 \mathrm{c}$ & up & colon cancer & (205) \\
\hline miR-204 & up & pancreatic tumor & (189) \\
\hline miR-205 & up & lung cancer & (190) \\
\hline miR-211 & up & pancreatic tumor & (189) \\
\hline miR-212 & up & pancreatic cancer & (188) \\
\hline miR-217 & down & pancreatic ductal adenocarcinoma & $(160)$ \\
\hline \multirow[t]{7}{*}{ miR-221 } & up & glioblastoma & $(48)$ \\
\hline & up & hepatocellular cancer & (193) \\
\hline & up & pancreatic cancer & (187) \\
\hline & up & pancreatic cancer & (188) \\
\hline & up & papillary thyroid carcinoma & (159) \\
\hline & up & papillary thyroid carcinoma & (100) \\
\hline & up & glioblastoma & (199) \\
\hline \multirow{4}{*}{$\operatorname{miR}-222$} & up & glioblastoma & $(48)$ \\
\hline & up & pancreatic cancer & (187) \\
\hline & up & papillary thyroid carcinoma & (159) \\
\hline & down & chronic lymphocytic leukemia & (201) \\
\hline
\end{tabular}




\begin{tabular}{|c|c|c|c|}
\hline miRNA & up/dor & cancer & ref \\
\hline & up & papillary thyroid carcinoma & $(100)$ \\
\hline miR-224 & up & hepatocellular carcinoma & (194) \\
\hline miR-301 & up & pancreatic cancer & (188) \\
\hline miR-320 & up & neuroblastoma & $(124)$ \\
\hline miR-342 & up & pancreatic tumor & $(189)$ \\
\hline miR-346 & up & thyroid cancer & $(195)$ \\
\hline miR-372 & up & testicular germ cell tumor & $(213)$ \\
\hline miR-373 & up & testicular germ cell tumor & (213) \\
\hline miR-375 & down & pancreatic cancer & $(188)$ \\
\hline miR-376a & up & pancreatic cancer & $(188)$ \\
\hline & down & chronic lymphocytic leukemia & $(203)$ \\
\hline miR-16-1, & down & chronic lymphocytic leukemia & $(140)$ \\
\hline $15 \mathrm{a}$ cluster & down & pituitary adenomas & $(214)$ \\
\hline & down & B-cell chronic lymphocvtic leukemias & $(63)$ \\
\hline & up & erythroleukemia & $(115)$ \\
\hline miR-17 & up & lung cancer cell line & $(121)$ \\
\hline cluster & up & lung cancer & $(77)$ \\
\hline & up & B-cell lymphomas & $(119)$ \\
\hline $\begin{array}{l}\text { miR-106a } \\
\text { cluster }\end{array}$ & up & T-cell leukemia & (116) \\
\hline
\end{tabular}


Table 3

miRNAs regulated by transcription factors

Oncogenic or tumor suppressive miRNAs that are directly modulated by transcription factors. The list contains miRNAs whose promoter region was analyzed by a luciferase reporter assay, and more importantly, was shown to bind to the transcription factor by chromatin immunoprecipitation assay

\begin{tabular}{|l|l|l|r|}
\hline $\begin{array}{l}\text { transcription } \\
\text { factor }\end{array}$ & target miRNA & note (cancer type, etc) & ref \\
\hline AR & miR-125b & prostate cancer & $(211)$ \\
\hline MYCN & miR-17-5p,-92,-320 & neuroblastoma & $(124)$ \\
\hline Twist & miR-10b & breast cancer & $(146)$ \\
\hline p53 & miR-34a, miR-34b-34c cluster & cell lines & $(60)$ \\
\hline p53 & miR-34a & cell lines & $(137)$ \\
\hline p53 & miR-34a, miR-34b-34c cluster cell lines and in vivo & $(215)$ \\
\hline STAT3 & miR-21 & myeloma cell lines & $(91)$ \\
\hline HIF & miR-26, -210 & & $(150)$ \\
\hline hypoxia) & miR-17-92 cluster & & $(125)$ \\
\hline E2F3 & miR-17-92 cluster & $(126)$ \\
\hline E2F1,2,3 & angiogenesis in colon cancer model $(147)$ \\
\hline Myc & miR-17-92 cluster & \\
\hline
\end{tabular}


Table 4

Oncogenic or tumor suppressive miRNAs and their direct target genes

The list are miRNAs and the target mRNAs where a directly regulatory connection was demonstrated by a luciferase assay using the 3'UTR of the mRNA

\begin{tabular}{|c|c|c|c|}
\hline miRNA & target gene & note (cancer type, etc) & ref \\
\hline let-7 & RAS & lung cancer & (98) \\
\hline let-7 & CCND2, CDK6, CDC25A & $\begin{array}{l}\text { cancer cell lines (A549, } \\
\text { HepG2, HeLa) }\end{array}$ & (59) \\
\hline let-7 & HMGA2 & ovarian cancer & $(132)$ \\
\hline let-7c & $\mathrm{c}-\mathrm{Myc}$ & liver tumors & $(83)$ \\
\hline let -7 & HMGA2 & lung cancer cell lines & $(38)$ \\
\hline let-7g & c-Myc, k-RAS & & $(70)$ \\
\hline let-7 & HMGA2 & & $(106)$ \\
\hline let-7 & NF2 & cholangiocarcinoma cell lines & (216) \\
\hline $\begin{array}{l}\operatorname{miR}-9,-125 a,- \\
125 b\end{array}$ & tropomyosin-related kinase C (trkC) & neuroblastoma & (107) \\
\hline miR-10b & HOXD10 & breast cancer & $(146)$ \\
\hline miR-16-1,-15a & $\mathrm{Bcl} 2$ & chronic lymphocytic leukemia & $(140)$ \\
\hline miR-17-5p & AIB1 & breast cancer & $(162)$ \\
\hline miR-17-5p, -20 & $\begin{array}{l}\text { Transforming growth factor- } \beta \text { receptor } \\
\text { type II (T } \beta \text { III) }\end{array}$ & & (74) \\
\hline $\operatorname{miR}-18$ & CTGF (connective tissue growth factor) & $\begin{array}{l}\text { colon cancer model of } \\
\text { angiogenesis }\end{array}$ & $(147)$ \\
\hline $\operatorname{miR}-19$ & thrombospondin-1 & $\begin{array}{l}\text { colon cancer model of } \\
\text { angiogenesis }\end{array}$ & $(147)$ \\
\hline miR-20a & $\mathrm{E} 2 \mathrm{~F} 1,2,3$ & & $(126)$ \\
\hline miR-21 & Pdcd4 & colorectal cancer & $(145)$ \\
\hline $\operatorname{miR}-21$ & PTEN & hepatocellular cancer & $(134)$ \\
\hline $\operatorname{miR}-21$ & tropomyosin 1 (TPM1) & & (47) \\
\hline $\operatorname{miR}-21$ & PTEN & cholangiocarcinoma & $(176)$ \\
\hline $\operatorname{miR}-27 b$ & CYP1B1 & breast cancer & $(210)$ \\
\hline $\operatorname{miR}-29 a, b, c$ & DNMT3A, DNMT3B & non small cell lung cancer & $(82)$ \\
\hline miR-29s & Mcl-1 & cholangiocarcinoma cell line & (84) \\
\hline miR-29b, $-181 b$ & TCL1 & chronic lymphocytic leukemia & $(202)$ \\
\hline miR-34a & E2F3 & neuroblastoma & (76) \\
\hline $\operatorname{miR}-34 a$ & $\begin{array}{l}\text { cyclin E2 (CCNE2), hepatocyte growth } \\
\text { factor receptor (MET) }\end{array}$ & & $(215)$ \\
\hline $\begin{array}{l}\operatorname{miR}-34 a,-34 b,- \\
34 c\end{array}$ & $\mathrm{Bcl} 2$ & non small cell lung cancer & (60) \\
\hline miR-106a cluster & $\begin{array}{l}\text { Mylip (myosin regulatory light chain- } \\
\text { interacting protein), Hipk3 } \\
\text { (homeodomain-interacting protein kinase } \\
\text { 3), Rbp1-like (retinoblastoma-binding } \\
\text { protein 1-like) }\end{array}$ & T-cell leukemia & (116) \\
\hline miR-122a & cyclin G1 & $\begin{array}{l}\text { hepatocellular cancer (HCC } \\
\text { vs. liver cirrhosis ) }\end{array}$ & $(193)$ \\
\hline $\operatorname{miR}-124 \mathrm{a}$ & cdk6 & colon cancer, lung cancer & $(80)$ \\
\hline $\operatorname{miR}-125 \mathrm{a},-125 \mathrm{~b}$ & ERBB2 and ERBB3 & breast cancer & $(144)$ \\
\hline miR-125b & Bak-1 & prostate cancer & $(211)$ \\
\hline $\operatorname{miR}-127$ & $\mathrm{Bcl6}$ & bladder (and prostate) cancer & $(217)$ \\
\hline miR-206 & ER alpha & breast cancer & $(105)$ \\
\hline miR-221, -222 & $\mathrm{p} 27$ (Kip) & glioblastoma & $(135)$ \\
\hline miR-221, -222 & $\mathrm{p} 27$ (Kip) & glioblastoma & $(48)$ \\
\hline miR-221, -222 & p27 (Kip) & prostate cancer & $(136)$ \\
\hline miR-372, -373 & LATS2 & testicular germ cell tumor & $(213)$ \\
\hline $\operatorname{miR}-378$ & Sufu, Fus-1 & U87 glioblastoma cell line & $(148)$ \\
\hline $\begin{array}{l}\text { BART 16, 17-5p, } \\
1-5 p \text { (EBV } \\
\text { encoded } \\
\text { miRNAs) } \\
\end{array}$ & LMP1 (EBV encoded oncogene) & nasopharyngeal carcinoma & $(111)$ \\
\hline $\begin{array}{l}\text { KSHV miRNAs } \\
\text { miR-K12-1, - } \\
\text { K12-3-3p, -K12- } \\
6-3 p,-K 12-11 \\
\end{array}$ & thrombospondin 1 (THBS1) & & $(112)$ \\
\hline
\end{tabular}


Table 5

miRNAs that affect the properties of cancer cells

Phenotypes of cells are described after ectopic expression (denoted as "+" in the second column) or inhibition ("--" in the second column) of a miRNA

\begin{tabular}{|c|c|c|c|}
\hline miRNA & effect on cell growth & Note (cancer type, etc) & ref \\
\hline let -7 & + inhibition of cell growth & lung cancer cell lines & (207) \\
\hline \multirow[t]{2}{*}{ let-7 } & + inhibition of cell growth (G1 arrest) & $\begin{array}{l}\text { A549 lung cancer line or } \\
\text { HepG2 cell line }\end{array}$ & \multirow[t]{2}{*}{$(59)$} \\
\hline & -enhanced cell growth & A549 lung cancer line & \\
\hline let-7c & + inhibition of cell growth (G1 accumulation) & Hepa-1 & $(83)$ \\
\hline let-7 & + inhibition of cell growth & lung cancer cell lines & $(38)$ \\
\hline \multirow{2}{*}{ let $-7 \mathrm{~g}$} & + inhibition of cell growth & & \multirow{2}{*}{$(70)$} \\
\hline & -enhanced cell growth & & \\
\hline let-7a-3 & $+\begin{array}{l}\text { increased anchorage independent growth } \\
\text { (soft agar assay) }\end{array}$ & A549 lung cancer line & (218) \\
\hline let-7 & $\begin{array}{l}\text { enhanced cytotoxicity (more apoptosis) by } \\
\text { gemcitabine, 5-FU, camptothecin }\end{array}$ & cholangiocarcinoma cell lines & (216) \\
\hline \multirow{2}{*}{$\begin{array}{l}\text { miR-9, - } \\
125 \mathrm{a},- \\
125 \mathrm{~b}\end{array}$} & $+\begin{array}{l}\text { inhibition of cell growth (decreased BrdU } \\
\text { incorporation) }\end{array}$ & \multirow[b]{2}{*}{ neuroblastoma } & \multirow{2}{*}{$(107)$} \\
\hline & $\begin{array}{l}\text { enhanced cell growth (rescue of RA-induced } \\
\text { growth arrest) }\end{array}$ & & \\
\hline \multirow{2}{*}{$\operatorname{miR}-10 b$} & $+\begin{array}{l}\text { increased migration, invasion, intravasation, } \\
\text { metastasis }\end{array}$ & & \multirow{2}{*}{$(146)$} \\
\hline & - decreased invasion & & \\
\hline $\begin{array}{l}\operatorname{miR}-16-1,- \\
15 \mathrm{a}\end{array}$ & + increased apoptosis & $\begin{array}{l}\text { megakaryocytic cell line } \\
\text { MEG-01 }\end{array}$ & (140) \\
\hline \multirow[t]{2}{*}{$\operatorname{miR}-17-5 \mathrm{p}$} & $\begin{array}{l}\text { inhibition of cell growth (adhesion } \\
\text { independent growth) }\end{array}$ & \multirow[t]{2}{*}{ breast cancer } & \multirow[t]{2}{*}{$(162)$} \\
\hline & - enhanced cell growth & & \\
\hline $\begin{array}{l}\text { miR-17-5p } \\
\text { and } 20 \mathrm{a}\end{array}$ & $\begin{array}{l}\text { inhibition of cell growth (increased } \\
\text { apoptosis) }\end{array}$ & $\begin{array}{l}\text { lung cancer cell line (Calu-6 } \\
\text { and ACC-LC-172) }\end{array}$ & (121) \\
\hline $\begin{array}{l}\operatorname{miR}-17- \\
5 \mathrm{p},-20\end{array}$ & $\begin{array}{l}\text { enhanced cell growth (adhesion independent } \\
\text { growth, in vitro culture and engrafted } \\
\text { tumor) }\end{array}$ & & (74) \\
\hline miR-20a & $\begin{array}{l}\text { increased apoptosis (in combination with } \\
\text { doxorubicin) }\end{array}$ & & (126) \\
\hline $\begin{array}{l}\text { miR-17-92 } \\
\text { cluster }\end{array}$ & + enhanced cell growth & $\begin{array}{l}\text { chronic myeloid leukemia cell } \\
\text { line }\end{array}$ & (219) \\
\hline $\begin{array}{l}\text { miR-17-92 } \\
\text { cluster }\end{array}$ & + increased angiogenesis & colon cancer model & (147) \\
\hline $\begin{array}{l}\text { miR-17-92 } \\
\text { cluster }\end{array}$ & + enhanced cell growth & lung cancer cell line & (77) \\
\hline $\operatorname{miR}-21$ & $\begin{array}{l}\text { +increased invasion, intravasation, metastasis } \\
\text { - decreased invasion, intravasation, metastasis }\end{array}$ & colorectal cancer & (145) \\
\hline $\operatorname{miR}-21$ & - $\begin{array}{l}\text { increased apoptosis (reduced tumor growth } \\
\text { upon inhibition by modified LNA in vivo) }\end{array}$ & glioblastoma & (177) \\
\hline miR-21 & $\begin{array}{l}\text { enhanced cell growth, increased migration } \\
\text { - inhibition of cell growth, decreased cell } \\
\text { migration and invasion }\end{array}$ & $\begin{array}{l}\text { hepatocellular cancer cell lines } \\
\text { and normal hepatocytes. }\end{array}$ & $(134)$ \\
\hline miR-21 & + decreased apoptosis upon IL-6 removal & myeloma cell line & $(91)$ \\
\hline miR-21 & $\begin{array}{l}\text { inhibition of cell growth (in vitro culture } \\
\text { and engrafted tumor), increased apoptosis }\end{array}$ & breast tumor & $(165)$ \\
\hline \multirow{2}{*}{ miR-21 } & $\begin{array}{l}\text { decreased cytotoxicity and less apoptosis } \\
\text { upon gemcitabine treatment (in vitro } \\
\text { culture) }\end{array}$ & \multirow{2}{*}{ cholangiocarcinoma } & \multirow{2}{*}{$(176$} \\
\hline & $\begin{array}{l}\text { increased cytotoxicity and more apoptosis } \\
\text { - upon gemcitabine treatment (in vitro } \\
\text { culture) }\end{array}$ & & \\
\hline miR-21 & - increased apoptosis & glioblastoma cell line & (209) \\
\hline miR-26, - & tincreased apoptosis & \multirow{2}{*}{$\begin{array}{l}\text { HIF (hypoxia)-induced } \\
\text { miRNAs }\end{array}$} & \multirow{2}{*}{$(150)$} \\
\hline $210,-107$ & - decreased apoptosis & & \\
\hline $\operatorname{miR}-27 \mathrm{a}$ & 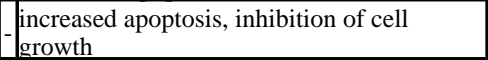 & breast cancer cell lines & (139) \\
\hline $\begin{array}{l}\operatorname{miR}-29 a \\
b, c\end{array}$ & $\begin{array}{l}\text { inhibition of cell growth (in vitro culture } \\
\text { and engrafted tumor), increased apoptosis }\end{array}$ & lung cancer cells & $(82)$ \\
\hline \multirow[b]{2}{*}{ miR-29b } & tincreased apoptosis & \multirow{2}{*}{$\begin{array}{l}\text { cholangiocarcinoma cell line } \\
\text { (tumor necrosis factor-related } \\
\text { apoptosis-inducing ligand } \\
\text { (TRAIL)-induced cell death) }\end{array}$} & \multirow[b]{2}{*}{ (84) } \\
\hline & - decreased apoptosis & & \\
\hline miR-34a & $\begin{array}{l}\text { inhibition of cell growth (in vitro culture } \\
+ \text { and engrafted tumor), senescence-like } \\
\text { phenotype }\end{array}$ & & $(58)$ \\
\hline
\end{tabular}




\begin{tabular}{|c|c|c|c|}
\hline miRNA & effect on cell growth & Note (cancer type, etc) & re \\
\hline miR-34a & + inhibition of cell growth (G1 accumulation) & & (137) \\
\hline $\operatorname{miR}-34 a$ & $+\begin{array}{l}\text { inhibition of cell growth (increased } \\
\text { apoptosis) }\end{array}$ & & (61) \\
\hline \multirow{2}{*}{ miR-34a } & $+\begin{array}{l}\text { inhibition of cell growth (increased } \\
\text { apoptosis) }\end{array}$ & & \multirow{2}{*}{$(141)$} \\
\hline & $-\begin{array}{l}\text { decreased apoptosis induced by genotoxic } \\
\text { stress }\end{array}$ & & \\
\hline $\operatorname{miR}-34 \mathrm{a}$ & + G1 accumulation & & $(60)$ \\
\hline $\operatorname{miR}-34 a$ & $+\begin{array}{l}\text { inhibition of cell growth (increased } \\
\text { apoptosis) }\end{array}$ & neuroblastoma cell lines & (76) \\
\hline $\begin{array}{l}\operatorname{miR}-34 a,- \\
34 \mathrm{~b},-34 \mathrm{c}\end{array}$ & $+\begin{array}{l}\text { inhibition of cell growth (G1 accumulation } \\
\text { and senescence) }\end{array}$ & & (215) \\
\hline $\begin{array}{l}\text { miR-34b } \\
\text { and }-34 c \\
\end{array}$ & $+\begin{array}{l}\text { inhibition of cell growth (adhesion } \\
\text { independent growth) }\end{array}$ & & (143) \\
\hline $\operatorname{miR}-98$ & + more resistant to doxorubicin & $\begin{array}{l}\text { primary human oral squamous } \\
\text { cell carcinoma cell lines }\end{array}$ & (149) \\
\hline $\begin{array}{l}\text { miR-106a } \\
\text { cluster }\end{array}$ & $++\begin{array}{l}\text { transformation of NIH3T3 (colony } \\
\text { formation assay) }\end{array}$ & & (116) \\
\hline $\begin{array}{l}\operatorname{miR}-125 \mathrm{a}, \\
-125 \mathrm{~b}\end{array}$ & $\begin{array}{l}\text { inhibition of cell growth, decreased } \\
\text { migration and invasion }\end{array}$ & breast cancer & (144) \\
\hline $\operatorname{miR}-125 b$ & tenhanced cell growth & prostate cancer cell lines & (211) \\
\hline miR-125b & -inhibition of cell growth & differentiated cell lines & $(173)$ \\
\hline $\begin{array}{l}\operatorname{miR}-125 b \\
-26 a\end{array}$ & + inhibition of cell growth & $\begin{array}{l}\text { FB-1 cells (thyroid cancer cell } \\
\text { line) }\end{array}$ & (67) \\
\hline $\begin{array}{l}\operatorname{miR}-143, \\
145\end{array}$ & + inhibition of cell growth & B-cell malignancies (Raji cell) & (212) \\
\hline miR-184 & $\begin{array}{l}\text { inhibition of cell growth (increased } \\
\text { apoptosis) }\end{array}$ & neuroblastoma cell lines & (69) \\
\hline $\begin{array}{l}\text { miR-197, } \\
346\end{array}$ & - inhibition of cell growth & thyroid cancer & (195) \\
\hline $\begin{array}{l}\text { miR-221, } \\
222\end{array}$ & inhibition of cell growth & glioblastoma & (135) \\
\hline $\begin{array}{l}\operatorname{miR}-221,- \\
222\end{array}$ & inhibition of cell growth (G1 block) & glioblastoma & (48) \\
\hline \multirow{2}{*}{$\begin{array}{l}\operatorname{miR}-221,- \\
222\end{array}$} & $\begin{array}{l}+\begin{array}{l}\text { enhanced cell growth (adhesion independent } \\
\text { growth) }\end{array} \\
\end{array}$ & $\begin{array}{l}\text { LNCaP prostate cancer cell } \\
\text { line }\end{array}$ & \multirow{2}{*}{$(136)$} \\
\hline & $\begin{array}{l}\text { inhibition of cell growth (adhesion } \\
\text { independent growth) }\end{array}$ & PC3 prostate cancer cell line & \\
\hline $\operatorname{miR}-221$ & + tenhanced cell growth & papillary thyroid carcinoma & (159) \\
\hline $\begin{array}{l}\text { miR-372, } \\
373 \\
\end{array}$ & $\begin{array}{l}\text { increased cell growth (adhesion independent } \\
\text { growth), decreased senescence }\end{array}$ & testicular germ cell tumor & (213) \\
\hline \multirow[t]{2}{*}{$\operatorname{miR}-378$} & $\begin{array}{l}\text { increased cell growth (in vitro culture and } \\
+ \text { engrafted tumor), reduced apoptosis, } \\
\text { enhanced angiogenesis }\end{array}$ & \multirow[t]{2}{*}{ U87 glioblastoma cell line } & \multirow[t]{2}{*}{$(148)$} \\
\hline & -inhibition of cell growth & & \\
\hline $\begin{array}{l}\text { EBV } \\
\text { encoded } \\
\text { BART } \\
\text { miRNAs }\end{array}$ & + decreased apoptosis & nasopharyngeal carcinoma & (111) \\
\hline
\end{tabular}

